\title{
Albumin Administration is Efficacious in the Management of Patients with Cirrhosis: A Systematic Review of the Literature
}

This article was published in the following Dove Press journal: Hepatic Medicine: Evidence and Research

\author{
Giacomo Zaccherini (iD \\ Manuel Tufoni (iD \\ Mauro Bernardi $(\mathbb{D}$ \\ Department of Medical and Surgical \\ Sciences, Alma Mater Studiorum - \\ University of Bologna, Bologna 40I38, \\ Italy
}

\begin{abstract}
The use of albumin in patients with cirrhosis has been extensively discussed over recent years. Current treatment approaches depend on targeting related complications, aiming to treat and/or prevent circulatory dysfunction, bacterial infections and multi-organ failure. Albumin has been shown to prolong survival and reduce complications in patients with cirrhosis. This review aims to ascertain whether the use of albumin is justified in patients with cirrhosis. A systematic review of randomized controlled trials (RCTs) and metaanalyses evaluating albumin use in patients with cirrhosis published between 1985 and February 2020 was conducted; the quality and risk of bias of the included studies were assessed. In total, 45 RCTs and 10 meta-analyses were included. Based on the included evidence, albumin is superior at preventing and controlling the incidence of cirrhosis complications vs other plasma expanders. Recent studies reported that long-term albumin administration to patients with decompensated cirrhosis improves survival with a $38 \%$ reduction in the mortality hazard ratio compared with standard medical treatment alone. Albumin infusions are justified for routine use in patients with cirrhosis, and the use of albumin either alone or in combination with other treatments leads to clinical benefits. Longterm administration of albumin should be considered in some patients.
\end{abstract}

Keywords: albumin, ascites, hepatorenal syndrome, liver cirrhosis, paracentesis, peritonitis

\section{Plain Language Summary}

Patients with decompensated cirrhosis have a poor prognosis, with most cases culminating in liver transplantation or early death. The management of these patients creates a heavy burden for healthcare systems, and effective treatments that able to prevent serious complications and improve patient quality of life and survival are therefore of great importance. For this reason, a systematic review was conducted to assess the suitability of albumin to treat patients with cirrhosis. The findings of the systematic review indicate that albumin is safe and effective for treating or preventing a multitude of complications arising from cirrhosis, including ascites, paracentesis-induced circulatory dysfunction, infections and hepatorenal syndrome. Therefore, in these contexts, albumin is recommended by international clinical practice guidelines for liver disease. Furthermore, long-term administration has recently been found to have a disease-modifying effect and prolong overall survival.

The current evidence base for the use of albumin to treat patients with cirrhosis is relatively large, but there are some areas that would benefit from additional research. These areas include the use of albumin in therapeutic paracentesis when the extracted volume of ascites is $<5 \mathrm{~L}$, in patients with cirrhosis and infections unrelated to spontaneous bacterial peritonitis, and longterm administration of albumin to further study the benefits on patient survival.
Correspondence: Mauro Bernardi Email mauro.bernardi@unibo.it 
More widespread use of albumin to treat the complications of decompensated cirrhosis, in line with international guidelines, will improve the quality of life and increase survival for patients with this serious condition, which is becoming more common and consequently having an increasing impact on healthcare resources.

\section{Introduction}

\section{Decompensated Cirrhosis}

Cirrhosis is the final disease stage of evolving chronic liver disease. ${ }^{1}$ The development of clinical manifestations such as ascites, hepatic encephalopathy (HE), gastrointestinal bleeding and severe jaundice, which occurs in 5-10\% of patients per year, ${ }^{2}$ marks the turning point between compensated and decompensated cirrhosis, an event associated with a dramatic worsening of prognosis. ${ }^{3}$ Ascites is the most frequent complication of cirrhosis, occurring in more than $50 \%$ of patients, which is associated with poor quality of life, increased risk of infections and increased mortality. ${ }^{4}$

The clinical course of decompensated cirrhosis is usually progressive, leading to liver transplantation or death. It is often accelerated by the onset of acute-onchronic liver failure (ACLF), a clinical syndrome precipitated by hepatic or systemic insults and characterized by hepatic and/or extra-hepatic organ failure and high shortterm mortality, despite its potential reversibility., Bacterial infections, to which patients with decompensated cirrhosis are highly susceptible because of a complex dysfunction of innate and acquired immunity, ${ }^{7}$ are among the most frequent causes of ACLF in the Western world.

The pathophysiological background of decompensated cirrhosis is a sustained inflammatory and pro-oxidant state due to the activation of immune cells resulting from the systemic spread of bacterial and bacterial products because of an abnormal translocation from the gut. ${ }^{8}$ Proinflammatory cytokines and highly reactive oxygen and nitrogen species are essential components of the pathophysiological pathways leading to systemic circulatory dysfunction and effective hypovolemia, a long-recognized feature of advanced cirrhosis. ${ }^{8,9}$ Systemic hemodynamic abnormalities and inflammation eventually lead to multiorgan dysfunction and, ultimately, failure. Agents that are able to improve effective blood volume and counteract one or more of these pathophysiological abnormalities could provide effective means to prevent complications and treat decompensated cirrhosis. ${ }^{10}$

\section{Albumin Properties}

Human albumin, produced in the liver, is the most abundant protein in plasma and maintains fluid balance in the body by regulating the oncotic pressure between the intraand extra-vascular spaces. ${ }^{11}$ Its oncotic power, prolonged half-life and ability to attract water from the interstitium to the intravascular compartment through indirect osmotic function make albumin a powerful plasma expander. ${ }^{12}$

Further to its role as a plasma expander, albumin also possesses several non-oncotic functions (Figure 1). The antioxidant activity of albumin cannot be ignored - it is the most abundant antioxidant in the body - and it also displays immune-modulatory activity, protection of capillary integrity, and regulation of acid-base balance and hemostasis. ${ }^{13}$ Albumin also binds a variety of endogenous and exogenous substances, including bilirubin, bile salts, endotoxins, and many drugs.

\section{Albumin Abnormalities in Cirrhosis}

Patients with advanced cirrhosis almost always present with reduced serum albumin concentration, which results from pathomechanisms including reduced synthesis by hepatocytes, dilution secondary to renal retention of sodium and water, and increased trans-capillary escape rate. ${ }^{14}$ All of these abnormalities are related to the progression of the underlying disease, and hypoalbuminemia is associated with reduced patient survival. ${ }^{15}$

However, serum albumin abnormalities in cirrhosis are not only quantitative, but also qualitative. Evidence suggests that the albumin molecule undergoes functional and structural changes in this setting, ${ }^{16-20}$ which worsens in parallel with the severity of cirrhosis. These abnormalities are also associated with the occurrence of additional complications and predict patient survival more closely than total serum albumin concentration. ${ }^{18-20}$ Thus, patients with advanced cirrhosis not only present a reduced total serum albumin concentration, but also, to an even greater extent, a reduction in the serum abundance of effective albumin, that is the native, functionally intact isoform of the molecule.

\section{The Use of Albumin in Cirrhosis}

Current guidelines recommend single-dose or short-term albumin administration to prevent or treat specific complications of cirrhosis characterized by an abrupt worsening of effective volemia. ${ }^{21,22}$ Most studies that have addressed the use of albumin in patients with cirrhosis were performed before evidence of the pathophysiological abnormalities 


\section{Albumin administration targets multiple complications in patients with cirrhosis}

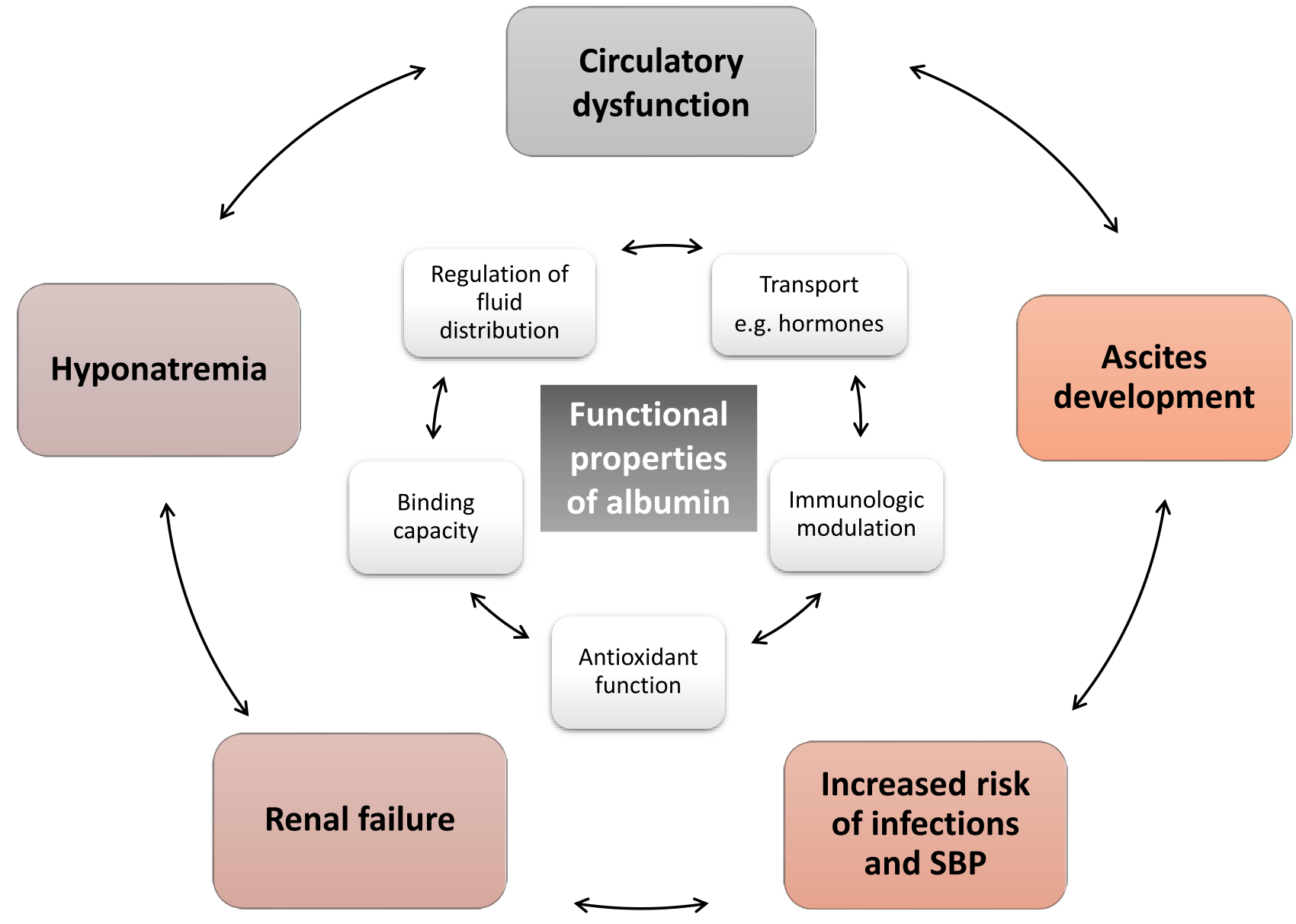

Figure I Functional properties of albumin and potential uses for cirrhosis complications. Data from Garcia- Martinez et al. ${ }^{13}$ Abbreviation: SBP, spontaneous bacterial peritonitis.

underlying the clinical manifestations of decompensated cirrhosis became available. ${ }^{8}$ In the light of the peripheral arterial vasodilation hypothesis, ${ }^{9}$ the main aim of albumin administration was directed at improving effective volemia. For these reasons, albumin effects have been compared with those of other means to enhance effective plasma volume, either fluids (artificial plasma expanders or saline solution) or vasoconstrictors.

The aim of the present systematic review of the literature was to identify and appraise studies that have compared the use of albumin with other available therapies in the management of decompensated cirrhosis, to ascertain whether the use of albumin is justified in these patients. This review focused on clinical parameters such as control of ascites and prevention of the main complications of cirrhosis, as well as patient-centered outcomes such as mortality and need for and duration of hospitalization.

\section{Methods}

The primary aim of this systematic review of the literature was to identify all relevant clinical studies evaluating the use of albumin in the management of patients with cirrhosis. The primary research question was "Is the use of albumin justified in the management of patients with cirrhosis?"

\section{Search Criteria}

A systematic literature search was conducted to retrieve original, English-language articles of interest from January 1985 to February 2020. The PubMed and EMBASE databases were searched with a combination of MeSH terms and key words for the population and interventions. The pre-defined search 
strategy utilized for PubMed was ("Albumin" OR "fluid administration" OR "fluid therapy" OR "fluid replacement") AND ("cirrhosis" OR "liver fibrosis" OR "liver disease"). Retrieved articles were limited to RCTs and meta-analyses. The pre-defined search strategy utilized for EMBASE is summarized in Tables 1 and 2. Reference lists of published articles were also examined to identify new studies of interest.

\section{Study Selection}

A two-stage process for screening and selection of relevant articles was conducted. Initial screening was based upon title and abstract only, against pre-defined inclusion and exclusion criteria (Table 3). The full texts of retained articles were examined to determine if they contained relevant information, using the same inclusion and exclusion criteria. Conflicts were resolved by an independent reviewer. The search and selection process was performed and described as per the Preferred Reporting Items for Systematic Reviews and Meta-Analyses (PRISMA) Statement. ${ }^{23}$

Table I EMBASE Search String (RCTs)

\begin{tabular}{|c|c|}
\hline Intervention & $\begin{array}{l}\text { "albumin" or "fluid administration" or } \\
\text { "fluid therapy" or "fluid replacement" }\end{array}$ \\
\hline Study setting & $\begin{array}{l}\text { "cirrhosis" or "liver fibrosis" or "liver disease" or } \\
\text { "liver ascites" }\end{array}$ \\
\hline Subjects & Human \\
\hline Article type & $\begin{array}{l}\text { "clinical trial"/de OR "randomized controlled } \\
\text { trial"/de OR "randomization"/de OR "single blind } \\
\text { procedure"/de OR "double blind procedure"/de } \\
\text { OR "crossover procedure"/de OR "placebo"/de } \\
\text { OR "prospective study"/de OR "randomi?ed } \\
\text { controlled" NEXT/l trial* OR rct OR "randomly } \\
\text { allocated" OR "allocated randomly" OR "random } \\
\text { allocation" OR allocated NEAR/2 random OR } \\
\text { single NEXT/I blind* OR double NEXT/I blind* } \\
\text { OR (treble OR triple) NEAR/I blind* OR placebo* }\end{array}$ \\
\hline $\begin{array}{l}\text { Excluded } \\
\text { article types }\end{array}$ & 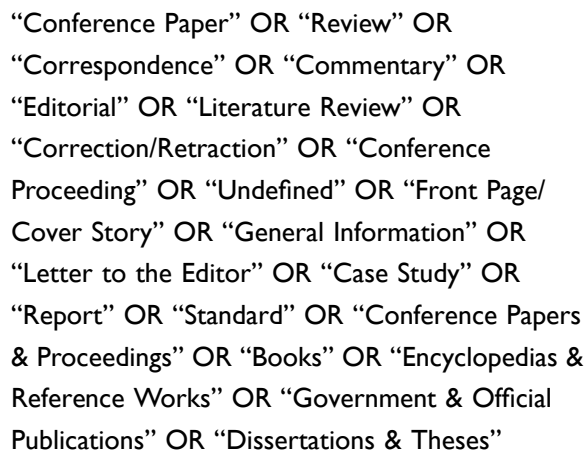 \\
\hline $\begin{array}{l}\text { Excluded } \\
\text { databases }\end{array}$ & NOT "Medline" \\
\hline
\end{tabular}

Table 2 EMBASE Search String (Meta-Analyses)

\begin{tabular}{|c|c|}
\hline Intervention & $\begin{array}{l}\text { "albumin" or "fluid administration" or "fluid } \\
\text { therapy" or "fluid replacement" }\end{array}$ \\
\hline Study setting & $\begin{array}{l}\text { "cirrhosis" or "liver fibrosis" or "liver disease" or } \\
\text { "liver ascites" }\end{array}$ \\
\hline Subjects & Human \\
\hline Article type & "meta analysis" OR meta-analysis \\
\hline $\begin{array}{l}\text { Excluded } \\
\text { article types }\end{array}$ & $\begin{array}{l}\text { "Conference Paper" OR "Review" OR } \\
\text { "Correspondence" OR “Commentary" OR } \\
\text { "Editorial" OR "Literature Review" OR } \\
\text { "Correction/Retraction" OR "Conference } \\
\text { Proceeding" OR "Undefined" OR "Front Page/ } \\
\text { Cover Story" OR "General Information" OR } \\
\text { "Letter to the Editor" OR "Case Study" OR } \\
\text { "Report" OR "Standard" OR "Conference Papers } \\
\text { \& Proceedings" OR "Books" OR "Encyclopedias \& } \\
\text { Reference Works" OR "Government \& Official } \\
\text { Publications" OR "Dissertations \& Theses" }\end{array}$ \\
\hline $\begin{array}{l}\text { Excluded } \\
\text { databases }\end{array}$ & NOT "Medline" \\
\hline
\end{tabular}

\section{Outcome Measures and Data Extraction}

Data were extracted from studies identified for inclusion using a data extraction form developed for this review, which included the following items: sample size, patient characteristics, duration of follow-up, mortality, and markers of disease progression (including changes in liver and renal function tests and circulatory dysfunction). In addition, we noted further complications that were reported

Table 3 Inclusion and Exclusion Criteria

\begin{tabular}{|c|c|}
\hline Inclusion Criteria & Exclusion Criteria \\
\hline $\begin{array}{l}\text { A. Articles published in } \\
\text { English }\end{array}$ & $\begin{array}{l}\text { F. Articles in any language other than } \\
\text { English }\end{array}$ \\
\hline B. Human subjects & $\begin{array}{l}\text { G. Non-clinical reports (eg animal } \\
\text { models, in vitro or ex vivo experimental } \\
\text { studies) }\end{array}$ \\
\hline $\begin{array}{l}\text { C. Randomized clinical } \\
\text { trials, meta-analyses }\end{array}$ & $\begin{array}{l}\text { H. Guidelines, retrospective studies, } \\
\text { systematic reviews, literature reviews, } \\
\text { editorials or commentaries }\end{array}$ \\
\hline $\begin{array}{l}\text { D. Patients with liver } \\
\text { cirrhosis }\end{array}$ & I. Healthy volunteers \\
\hline $\begin{array}{l}\text { E. Use of albumin for } \\
\text { volume replacement }\end{array}$ & $\begin{array}{l}\text { J. Studies that do not assess the efficacy } \\
\text { of albumin in cirrhosis, studies that use } \\
\text { albumin dialysis, studies that only use } \\
\text { albumin as part of a treatment procedure }\end{array}$ \\
\hline
\end{tabular}


and recorded whether these adverse events were serious and considered to be treatment-related.

\section{Assessment of Risk of Bias}

The quality and risk of bias of the included studies were assessed using checklists adapted from those produced by the Scottish Intercollegiate Guidelines Network (SIGN). ${ }^{24}$ The potential risk of bias was assigned based on assessment of the following: allocation concealment, sequence generation and blinding of outcomes, sample size, withdrawals and reporting bias. Each study was graded as level 1 evidence, because only RCTs were included (representing the highest level of evidence), and then as "++", “+”, or “-”, denoting low, acceptable or high risk of bias, respectively, according to the number of potential biases identified.

\section{Results}

\section{Characteristics of the Selected Studies}

The initial search identified 514 RCTs and 117 metaanalyses published since 1985 , of which 45 RCTs and 10 meta-analyses were retained after screening. The study selection process is presented in a detailed PRISMA flow diagram (Figure 2).

An overview of the risk of different biases across all the included RCTs and meta-analyses is presented in Figure 3. Of the 45 included RCTs, $11(24 \%)$ were rated $1++,{ }^{25-35} 31$ $(69 \%)$ as $1+,{ }^{36-66}$ and $3(7 \%)$ as $1-,{ }^{67-69}$ based on the assessed risk of bias. This suggests that most studies included were high-quality, well-conducted trials with acceptable or low risk of bias. Of the 10 meta-analyses included, 3 (30\%) were rated as $1++,{ }^{70-72} 6(60 \%)$ as $1+,{ }^{73-78}$ and $1(10 \%)$ as $1-,{ }^{79}$ based on the SIGN grading recommendations. ${ }^{24}$

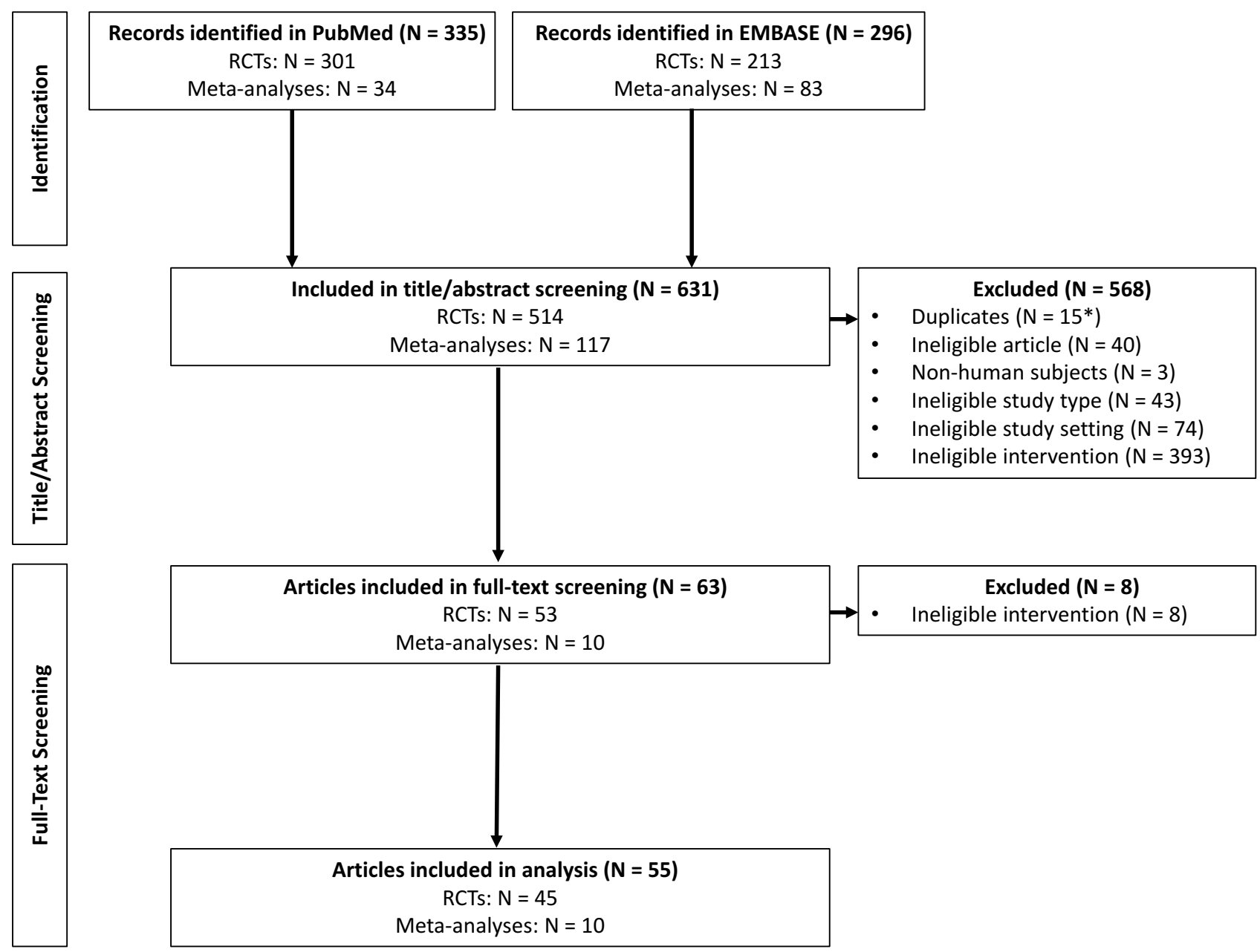

Figure 2 PRISMA flow diagram summarizing the results from PubMed and EMBASE searches.

Notes: Adapted from Moher D, Liberati A, Tetzlaff J, Altman DG, Group P. Preferred reporting items for systematic reviews and meta-analyses: the PRISMA statement. Ann Intern Med. 2009;15I(4):264-269, W264. Creative Commons license and disclaimer available from: (http://creativecommons.org/licenses/by/4.0/legalcod). ${ }^{23} *$ Embase searches were designed to exclude PubMed/Medline records, but 15 studies identified in Embase were nonetheless duplicates from PubMed/Medline. 
Low risk of bias

Unclear risk of bias

High risk of bias

\section{Randomized controlled trials (RCTs)}

Allocation of intervention not randomized (selection bias) Inadequate concealment method (selection bias)

Study was not Double-blinded study (detection bias) Small sample size; <100 participants (detection bias) Inadequate description of withdrawals (detection bias) Selective reporting (reporting bias)

Other bias; e.g., Pharma funding (reporting bias)

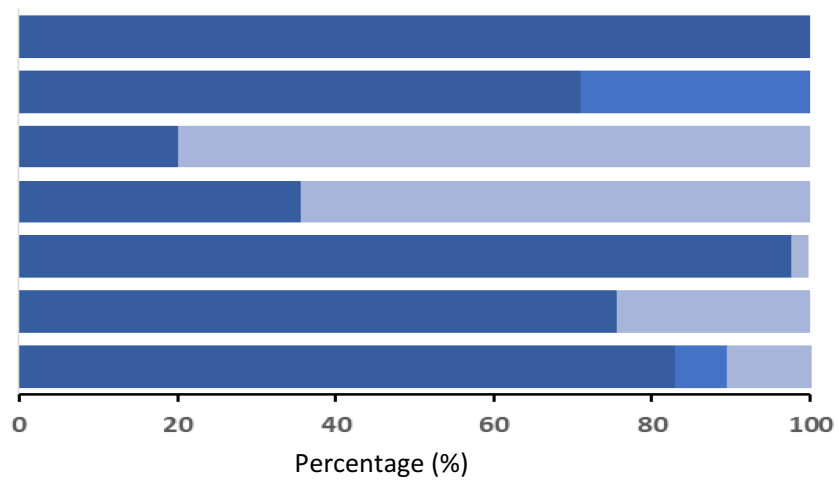

\section{Meta-analyses}

Comprehensive literature search (selection bias)

Studies not selected by at least two people (detection bias)

Data not extracted by at least two people (detection bias)

Included studies well described (detection bias)

Excluded studies well described (detection bias)

Quality of studies not assessed and reported (reporting bias) Inadequate methods to combine results (reporting bias)

Bias assessment completed (reporting bias)

Conflicts declared (reporting bias)

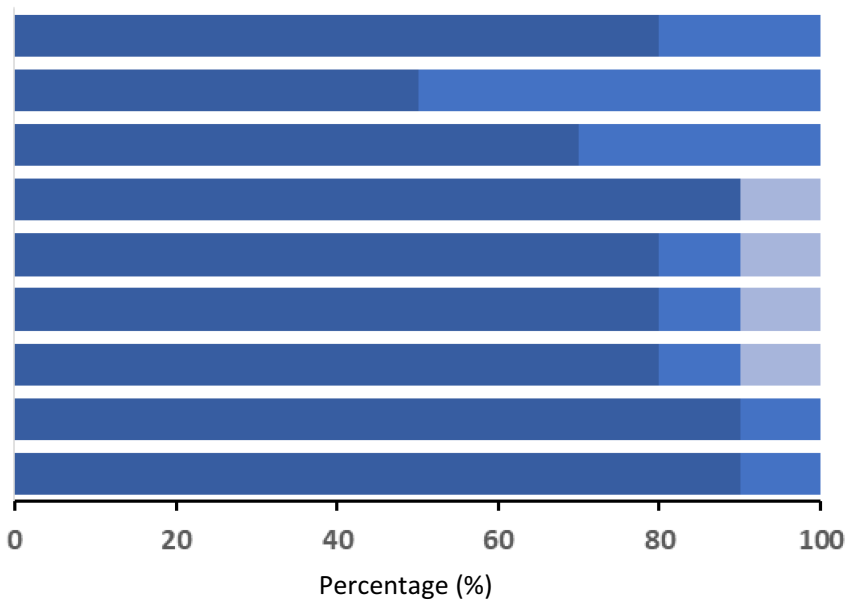

Figure 3 Risk of bias across all included studies ( $n=45$ RCTs, $n=10$ meta-analyses), as assessed using criteria adapted from the SIGN guidelines.

Notes: Adapted from Scottish Intercollegiate Guidelines Network (SIGN). SIGN GRADING SYSTEM 1999 - 2012. Available from: (https://www.sign.ac.uk/assets/sign_ grading_system_1999_2012.pdf). Creative Commons license and disclaimer available from: (http://creativecommons.org/licenses/by/4.0/legalcode). ${ }^{24}$

Abbreviation: SIGN, Scottish Intercollegiate Guidelines Network.

There were 14 RCTs that compared albumin with alternative plasma expanders, ${ }^{27,30,40,42,49-53,55,59-61,68} 14$ studies assessed albumin combined with or vs a vasoconstrictor (terlipressin in 7 studies, ${ }^{26,37,45,47,54,65,66}$ midodrine in 5 studies $^{25,39,44,46,64}$ and noradrenaline in 2 studies $^{36,48}$ ), while 4 studies assessed the use of diuretics instead of albumin. ${ }^{34,35,62,63}$ Other studies evaluated lower doses of albumin $^{43}$ and reinfusion of concentrated ascitic fluid as alternatives to albumin infusion. ${ }^{58,67}$ In addition, 5 studies reported on the benefits of antibiotics used in combination with albumin in patients with SBP. ${ }^{31,38,69,80}$ Table 4 provides an overview of the highest-quality RCTs $(1++)$ included in this review. ${ }^{25-35}$

\section{Efficacy of Albumin in Patients with Cirrhosis}

Paracentesis-Induced Circulatory Dysfunction (PICD)

PICD is a complication that arises following the removal of ascitic fluid and may lead to severe consequences such as arterial hypotension, renal dysfunction, hyponatremia, HE, or even death. ${ }^{81}$ The current recommendation from the European Association for the Study of the Liver (EASL) and the American Association for the Study of Liver Diseases (AASLD) is $8 \mathrm{~g}$ of albumin for every liter of ascites removed by large-volume paracentesis (LVP) exceeding $5 \mathrm{~L}^{21,22}$ It is yet to be defined whether 
Table 4 Summary of the Highest-Quality RCTs $(I++; n=I I)$ Included in This Systematic Review, Assessed According to Adapted SIGN Criteria ${ }^{24}$

\begin{tabular}{|c|c|c|c|c|}
\hline Study & $\begin{array}{l}\text { Treatment } \\
\text { Intervention } \\
\text { (N, Patients) }\end{array}$ & $\begin{array}{l}\text { Comparator } \\
\text { Intervention } \\
\text { (N, Patients) }\end{array}$ & Key Endpoint(s) & $\begin{array}{l}\text { Key Findings: Observed } \\
\text { Complication Rates (Albumin- } \\
\text { Containing Intervention vs } \\
\text { Comparator(s)) }\end{array}$ \\
\hline \multicolumn{5}{|c|}{ Albumin in paracentesis } \\
\hline $\begin{array}{l}\text { Boyer et al, } 2016^{26} \\
\text { (Double blind) }\end{array}$ & $\begin{array}{l}\text { Terlipressin + Albumin } \\
\text { ( } 97 \text { ) } \\
\text { I mg terlipressin every } 6 \\
\mathrm{~h}+20-40 \text { g/day albumin } \\
\text { for up to } 14 \text { days }\end{array}$ & $\begin{array}{l}\text { Placebo }+ \text { Albumin }(99) \\
\text { I } \mathrm{mg} \text { placebo }+20-40 \mathrm{~g} / \\
\text { day albumin for up to } 14 \\
\text { days }\end{array}$ & $\begin{array}{l}\text { Primary: percentage of } \\
\text { patients with } \\
\text { confirmed HRS } \\
\text { reversal } \\
\text { Secondary: incidence } \\
\text { of HRS reversal, } \\
\text { transplant-free } \\
\text { survival, overall } \\
\text { survival }\end{array}$ & $\begin{array}{l}\text { - Confirmed HRS reversal: } 19 / 97 \\
(19.6 \%) \text { vs } 13 / 99(13.1 \%) \text { patients } \\
\text { ( } p=0.22 \text {, not significant) } \\
\text { - Probability of surviving without trans- } \\
\text { plantation at } 90 \text { days: } 0.308 \text { vs } 0.248 \\
\text { ( } p=0.56) \\
\text { - Survival at } 90 \text { days: } 56 / 97(57.7 \%) \text { vs } \\
54 / 99(54.5 \%) \text { patients }(p=0.60)\end{array}$ \\
\hline $\begin{array}{l}\text { Bari et al, } 2012^{27} \\
\text { (Double blind) }\end{array}$ & $\begin{array}{l}\text { Albumin (I3) } \\
8 \mathrm{~g} / \mathrm{L} \text { of ascites removed }\end{array}$ & $\begin{array}{l}\text { Midodrine + Octreotide } \\
(12) \\
10 \mathrm{mg} \text { midodrine three } \\
\text { times a day + octreotide } \\
\text { LAR } 20 \mathrm{mg} \text { every month }\end{array}$ & $\begin{array}{l}\text { Primary: recurrence of } \\
\text { ascites requiring LVP, } \\
\text { mortality, liver } \\
\text { transplant }\end{array}$ & $\begin{array}{l}\text { - Median time to recurrent ascites: } 10 \\
\text { days vs } 8 \text { days } \\
\text { - Development of PICD: } 18 \% \text { vs } 25 \% \\
\text { ( }=0.574 \text {, not significant) } \\
\text { - Liver transplantation required: } 2 \\
\text { patients vs } 2 \text { patients } \\
\text { - Mortality after } 10 \text { months: } 4 \text { patients } \\
\text { vs } 5 \text { patients }\end{array}$ \\
\hline $\begin{array}{l}\text { Gines et al, } 1996^{30} \\
\text { (Non-blinded) }\end{array}$ & $\begin{array}{l}\text { Albumin ( } 97) \\
20 \% \text { albumin at } 8 \mathrm{~g} / \mathrm{L} \text { of } \\
\text { ascites removed (first } 50 \% \\
\text { in } 2 \mathrm{~h} \text {, second } 50 \% 6-8 \\
\mathrm{~h} \text { after LVP) }\end{array}$ & $\begin{array}{l}\text { Dextran-70 (93), or } \\
\text { Gelatin (99) } \\
8 \mathrm{~g} / \mathrm{L} \text { ascites removed }\end{array}$ & $\begin{array}{l}\text { Primary: evaluate the } \\
\text { efficacy of plasma } \\
\text { expanders in } \\
\text { preventing PICD and } \\
\text { investigate effects of } \\
\text { PICD on mortality and } \\
\text { morbidity }\end{array}$ & $\begin{array}{l}\text { - Incidence of PICD: } 17 / 92 \text { (18.5\%) vs } \\
31 / 90 \text { (34.4\%) vs } 37 / 98 \text { (37.8\%) (sig- } \\
\text { nificant difference) } \\
\text { - Mortality: } 2 \text { patients vs } 4 \text { patients vs } 6 \\
\text { patients }\end{array}$ \\
\hline $\begin{array}{l}\text { Gines et al, } 1988^{29} \\
\text { (Non-blinded) }\end{array}$ & $\begin{array}{l}\text { Paracentesis + Albumin } \\
(52) \\
20 \% \text { albumin at } 40 \mathrm{~g} \text { after } \\
4-6 \mathrm{~L} / \text { day ascites removed }\end{array}$ & $\begin{array}{l}\text { Paracentesis (53) } \\
\text { 4-6 L/day ascites removed }\end{array}$ & $\begin{array}{l}\text { Investigate whether IV } \\
\text { albumin infusion is } \\
\text { necessary in the } \\
\text { treatment of } \\
\text { cirrhotics with LVP }\end{array}$ & $\begin{array}{l}\text { - Ascites eliminated in: } 50 / 52(96 \%) \text { vs } \\
48 / 53(90.5 \%) \text { patients } \\
\text { - Serious complications developed in: } \\
9 / 52(17 \%) \text { vs } 16 / 53(30 \%) \text { patients } \\
\text { - Hospital readmissions required in: } \\
29 / 52 \text { patients vs } 36 / 53 \text { patients }\end{array}$ \\
\hline $\begin{array}{l}\text { Gines et al, } 1987^{28} \\
\text { (Non-blinded) }\end{array}$ & $\begin{array}{l}\text { Paracentesis + Albumin } \\
(58) \\
20 \% 40 \mathrm{~g} \text { albumin after } 4- \\
6 \mathrm{~L} / \text { day ascites removed }\end{array}$ & $\begin{array}{l}\text { Spironolactone + } \\
\text { Furosemide (59) } \\
200-400 \mathrm{mg} / \text { day } \\
\text { spironolactone + } \\
40-240 \mathrm{mg} / \text { day } \\
\text { furosemide }\end{array}$ & $\begin{array}{l}\text { Compare paracentesis } \\
\text { associated with } \\
\text { albumin vs diuretics to } \\
\text { treat tense ascites }\end{array}$ & $\begin{array}{l}\text { - Percentage of patients responding to } \\
\text { treatment: } 56 / 58(96.5 \%) \text { vs } 43 / 59 \\
(72.8 \%) \text { patients }(p<0.05 \text {, significant } \\
\text { difference) } \\
\text { - Incidence of complications: } 10 \\
\text { patients vs } 36 \text { patients }(p<0.00 \mathrm{I}) \\
\text { - Duration of hospital stay: } 11.7 \pm 1.5 \\
\text { days vs } 31 \pm 2.8 \text { days }(p<0.00 \mathrm{I})\end{array}$ \\
\hline
\end{tabular}

(Continued) 
Table 4 (Continued).

\begin{tabular}{|c|c|c|c|c|}
\hline Study & $\begin{array}{l}\text { Treatment } \\
\text { Intervention } \\
\text { (N, Patients) }\end{array}$ & $\begin{array}{l}\text { Comparator } \\
\text { Intervention } \\
\text { (N, Patients) }\end{array}$ & Key Endpoint(s) & $\begin{array}{l}\text { Key Findings: Observed } \\
\text { Complication Rates (Albumin- } \\
\text { Containing Intervention vs } \\
\text { Comparator(s)) }\end{array}$ \\
\hline \multicolumn{5}{|c|}{ Albumin in SBP/non-SBP infections } \\
\hline $\begin{array}{l}\text { Sort et al, } 1999^{31} \\
\text { (Double blind) }\end{array}$ & $\begin{array}{l}\text { Cefotaxime }+ \text { Albumin } \\
(63) \\
\mathrm{I}-2 \mathrm{~g} \text { every } 6-12 \mathrm{~h}^{*}+1.5 \\
\mathrm{~g} / \mathrm{kg} \text { in the first } 6 \mathrm{~h} \text {, then I } \\
\mathrm{g} / \mathrm{kg} \text { on day } 3\end{array}$ & $\begin{array}{l}\text { Cefotaxime (63) } \\
\mathrm{I}-2 \mathrm{~g} \text { every } 6-12 \mathrm{~h}^{*}\end{array}$ & $\begin{array}{l}\text { Primary: development } \\
\text { of renal impairment } \\
\text { and mortality }\end{array}$ & $\begin{array}{l}\text { - Incidence of renal impairment: } 6 / 63 \\
\text { ( } 10 \% \text { ) vs } 21 / 63(33 \%) \text { patients } \\
\text { - Morality: } 10 \% \text { vs } 29 \% \text { patients } \\
\text { ( } p=0.0 \text { I, significant difference) } \\
\text { - Mortality at } 3 \text { months: } 14 / 63(22 \%) \text { vs } \\
26 / 63 \text { (4I\%) patients (significant } \\
\text { difference) }\end{array}$ \\
\hline $\begin{array}{l}\text { Fernandez et al, } \\
2019^{32} \text { (Open- } \\
\text { label) }\end{array}$ & $\begin{array}{l}\text { Antibiotics }+ \text { albumin }(6 \mathrm{I}) \\
20 \% \text { albumin I.5 g/kg body } \\
\text { weight at day I then I g/ } \\
\mathrm{kg} \text { body weight at day } 3 ; \\
\text { antibiotics provided based } \\
\text { on identified infection }\end{array}$ & $\begin{array}{l}\text { Antibiotics alone (57) } \\
\text { Antibiotics provided } \\
\text { based on identified } \\
\text { infection }\end{array}$ & $\begin{array}{l}\text { Primary: in-hospital } \\
\text { mortality Secondary: } \\
\text { effect of albumin on } \\
\text { disease course }\end{array}$ & $\begin{array}{l}\text { - No significant difference in the pri- } \\
\text { mary outcome between groups } \\
\text { ( } 13.1 \% \text { vs } 10.5 \%, p=0.66) \\
\text { - A significantly higher proportion of } \\
\text { patients in the study group had reso- } \\
\text { lution of ACLF ( } 82.3 \% \text { vs } 33.3 \% \text {, } \\
\mathrm{P}=0.03) \\
\text { - A significantly lower proportion of } \\
\text { patients in the study group devel- } \\
\text { oped nosocomial infections }(6.6 \% \text { vs } \\
24.6 \%, \mathrm{p}=0.007)\end{array}$ \\
\hline \multicolumn{5}{|c|}{ Long-term use of albumin } \\
\hline $\begin{array}{l}\text { Sola et al, } 2018, \\
\text { MACHT study } \\
\text { (Double blind) }\end{array}$ & $\begin{array}{l}\text { Midodrine + albumin ( } 87) \\
\text { I } 5-30 \mathrm{mg} / \text { day midodrine } \\
+40 \mathrm{~g} 20 \% \text { albumin every } \\
\text { I5 days for up to I year }\end{array}$ & $\begin{array}{l}\text { Placebo ( } 86) \\
0.9 \% \text { saline every I } 5 \text { days } \\
\text { for up to I year }\end{array}$ & $\begin{array}{l}\text { Incidence of } \\
\text { complications of } \\
\text { cirrhosis including: } \\
\text { renal failure, } \\
\text { hyponatremia, } \\
\text { infections, HE, } \\
\text { gastrointestinal } \\
\text { bleeding }\end{array}$ & $\begin{array}{l}\text { - Observed rate of complications in: } \\
37 \% \text { vs } 43 \% \\
\text { - Mortality: } 7 \% \text { patients vs } 5 \% \text { patients } \\
\text { - Treatment related adverse events: } 54 \\
\text { vs } 36 \text { events }\end{array}$ \\
\hline $\begin{array}{l}\text { Caraceni et al, } \\
2018 \text { ANSWER } \\
\text { study }{ }^{33} \text { (Open- } \\
\text { label) }\end{array}$ & $\begin{array}{l}\text { SMT + Albumin ( } 2 \text { I8) } \\
40 \text { g albumin twice weekly } \\
\text { for } 2 \text { weeks, and then } 40 \\
\text { g weekly, with SMT: anti- } \\
\text { aldosteronic drugs } \\
\text { ( } \geq 200 \mathrm{mg} / \text { day) and } \\
\text { furosemide ( } \geq 25 \mathrm{mg} / \text { day), } \\
\text { for up to } 18 \text { months }\end{array}$ & $\begin{array}{l}\text { SMT }(2 / 3) \\
\text { SMT: anti-aldosteronic } \\
\text { drugs ( } \geq 200 \mathrm{mg} / \text { day) and } \\
\text { furosemide }(\geq 25 \mathrm{mg} / \text { day), } \\
\text { for up to } 18 \mathrm{months}\end{array}$ & $\begin{array}{l}\text { Primary: 18-month } \\
\text { mortality } \\
\text { Secondary: number of } \\
\text { paracentesis, } \\
\text { hyponatremia and } \\
\text { incidence of cirrhotic } \\
\text { complications }\end{array}$ & $\begin{array}{l}\text { - I8-month all-cause mortality: } 0.27 \\
\text { deaths per person vs } 0.44 \text { deaths } \\
\text { per person (significant difference) } \\
\text { - Probability of remaining paracentesis } \\
\text { free: } 62 \% \text { vs } 34 \%(p<0.000 \text { I) } \\
\text { - Cumulative incidence of refractory } \\
\text { ascites: } 0.25 \text { vs } 0.48(p<0.000 \text { I) }\end{array}$ \\
\hline
\end{tabular}

(Continued) 
Table 4 (Continued).

\begin{tabular}{|c|c|c|c|c|}
\hline Study & $\begin{array}{l}\text { Treatment } \\
\text { Intervention } \\
\text { (N, Patients) }\end{array}$ & $\begin{array}{l}\text { Comparator } \\
\text { Intervention } \\
\text { (N, Patients) }\end{array}$ & Key Endpoint(s) & $\begin{array}{l}\text { Key Findings: Observed } \\
\text { Complication Rates (Albumin- } \\
\text { Containing Intervention vs } \\
\text { Comparator(s)) }\end{array}$ \\
\hline $\begin{array}{l}\text { Romanelli et al, } \\
2006^{34} \\
\text { (Non-blinded) }\end{array}$ & $\begin{array}{l}\text { Albumin + Diuretics }(54) \\
25 \mathrm{~g} \text { albumin per week for } \\
\text { the first year, followed by } \\
25 \mathrm{~g} \text { every } 2 \text { weeks for } 2 \\
\text { years, + Spironolactone } \\
(100-400 \mathrm{mg})+ \\
\text { furosemide }(25-150 \mathrm{mg}) \text {, } \\
\text { as appropriate }\end{array}$ & $\begin{array}{l}\text { Diuretics }(46) \\
\text { Spironolactone } \\
(100-400 \mathrm{mg})+ \\
\text { furosemide }(25-150 \mathrm{mg}) \text {, } \\
\text { as appropriate }\end{array}$ & $\begin{array}{l}\text { Primary: long-term } \\
\text { survival without liver } \\
\text { transplant } \\
\text { Secondary: recurrence } \\
\text { of ascites and other } \\
\text { complications }\end{array}$ & $\begin{array}{l}\text { - Transplant-free survival at } 24 \\
\text { months: } 34 / 54(75 \%) \text { vs } 26 / 46(68 \%) \\
\text { patients } \\
\text { - Transplant-free survival at } 48 \\
\text { months: } 3 \text { I }(69 \%) \text { vs II }(29 \%) \\
\text { patients } \\
\text { - Recurrence of ascites: } 21 / 54 \\
\text { ( } 38.88 \%) \text { vs } 39 / 46(84.78 \%) \\
(p<0.000 \text { I, significant difference) }\end{array}$ \\
\hline $\begin{array}{l}\text { Gentilini et al, } \\
1999^{35} \\
\text { (Non-blinded) }\end{array}$ & $\begin{array}{l}\text { Albumin + Diuretics (63) } \\
25 \mathrm{~g} \text { albumin once a week } \\
\text { in the first year, followed } \\
\text { by } 25 \mathrm{~g} \text { every } 2 \text { weeks in } \\
\text { the second and third years }\end{array}$ & $\begin{array}{l}\text { Diuretics (63) } \\
\text { Potassium canrenoate } \\
200 \mathrm{mg}+\text { furosemide } \\
25 \mathrm{mg} / \text { day }\end{array}$ & $\begin{array}{l}\text { Primary: evaluate the } \\
\text { benefits of albumin in } \\
\text { patients with ascites } \\
\text { receiving diuretics }\end{array}$ & $\begin{array}{l}\text { - Developed ascites during follow up: } \\
21 / 63(33.3 \%) \text { vs } 31 / 63(49.2 \%) \\
\text { patients } \\
\text { - Mean hospital stay: } 16.6 \pm 1.28 \text { days } \\
\text { vs } 25.9 \pm 2.1 \text { days }(p<0.00 \mathrm{I}) \\
\text { - Hospital readmissions: } 40 \text { in } 28 \\
\text { patients vs } 32 \text { in } 22 \text { patients } \\
\text { ( } p<0.02 \text {, significant difference) }\end{array}$ \\
\hline
\end{tabular}

Note: *Depending on serum creatinine levels.

Abbreviations: h, hour; HE, hepatic encephalopathy; HRS-I, hepatorenal syndrome type-I; IV, intravenous; LVP, large-volume paracentesis; PICD, paracentesis-induced circulatory dysfunction; SIGN, Scottish Intercollegiate Guidelines Network; SMT, standard medical treatment.

alternative products such as artificial plasma expanders and/or vasoconstrictors should be used after $<5$ $\mathrm{L}$ therapeutic paracentesis.

\section{Is Albumin Useful in Preventing PICD?}

In patients not receiving a plasma expander following paracentesis, the development of PICD is often seen within 24 hours and may become further complicated by the rapid recurrence of ascites. ${ }^{56,57}$ Using albumin as a plasma expander in patients treated with LVP is a fast, effective and well-tolerated therapy that reduces renal impairment and prevents the development of complications. $^{28,29,62}$

Based on the meta-analysis by Kwok et al, which included 1518 patients from 16 studies, the incidence of PICD can be significantly reduced (odds ratio [OR] 0.26, 95\% confidence interval [CI] 0.08-0.93) if patients are treated with paracentesis followed by plasma volume expansion with albumin. ${ }^{75}$ This meta-analysis also found that mortality was significantly reduced in patients with cirrhosis presenting with an infection who were treated with paracentesis following by albumin infusion when compared with no albumin (OR $0.46,95 \%$ CI $0.25-0.86){ }^{75}$
Yakar et al compared intravenous furosemide plus 3\% saline vs oral furosemide and salt vs repeated LVP plus albumin in patients with refractory ascites. Although this was a small study involving 78 cirrhotic patients with a relatively limited follow-up time ( $\sim 14$ months), the authors proposed that high-dose oral furosemide with salt ingestion may be an effective alternative to albumin administration following LVP, based on their observation of fewer patients developing SBP and a lower rate of mortality. ${ }^{63}$ Other investigators previously reported that hypertonic saline solution plus high dose furosemide may be an alternative to repeated paracentesis based on results of a pilot study ${ }^{82}$ or have potentially beneficial metabolic effects (citations not included in the assessment of bias). ${ }^{83}$

\section{Is Albumin Better Than Other Volume Expanders in Preventing PICD?}

Various other plasma expanders, such as dextran-70, dextran-40, gelatin (polygeline) and hydroxyethyl starch (HES), have been investigated as potential alternatives to albumin administration. Dextran-70 can be used as an effective plasma expander for the treatment of patients with cirrhosis and tense ascites. ${ }^{59}$ However, albumin is 
more efficacious than dextran at preventing the decrease in intravascular volume that follows paracentesis and potentially leads to PICD. ${ }^{61}$ Gelatin has been proposed to have similar protective effects to albumin after LVP, but its short half-life ( $<5$ hours) means that it is rapidly excreted and its effects as a plasma expander cannot be sustained. ${ }^{30,60}$ The development of PICD in the days following LVP suggests that the follow-up period is essential for monitoring the development of complications. ${ }^{51}$ Degoricija et al $(\mathrm{N}=30)$ found that albumin is superior to other plasma expanders for treating patients with tense ascites, with a lower incidence of complications such as renal impairment. ${ }^{51}$ In addition, fewer patients receiving albumin develop liver-related complications compared with patients receiving gelatin, which is associated with reduced follow-up hospitalization costs and is important for patients' wellbeing. ${ }^{49}$ HES is sometimes used as a plasma expander and a potential alternative to albumin in the treatment of patients with cirrhosis. It is thought that HES may have similar effects to albumin; however, the short-term differences between outcomes observed are not of clinical importance and the long-term effects of HES with regards to both efficacy and safety have not been demonstrated in patients with cirrhosis; ${ }^{68}$ therefore, HES should not be used after LVP in patients with cirrhosis. ${ }^{84}$

In 2012, the first meta-analysis $(\mathrm{N}=1225)$ comparing the effectiveness of plasma expanders (albumin, dextran, saline, HES and gelatin) and vasoconstrictors (terlipressin, epinephrine and midodrine) as an adjunct to LVP concluded that administration of albumin following LVP was more effective at reducing mortality and morbidity compared with the other agents. ${ }^{71}$ The risk of mortality was $36 \%$ lower in the albumin group (50 of 414 patients) compared with alternative treatments (74 of 513 patients $[p=0.038]$ ), supporting its use in clinical practice as the first-choice treatment for patients requiring LVP. A more recent meta-analysis found that albumin was significantly more effective than other plasma expanders at reducing hyponatremia, as well as PICD, in patients without hepatocellular carcinoma (HCC). ${ }^{77}$ The authors also reported a trend towards mortality reduction of $22 \%$ in response to albumin administration. Despite this, Kutting et al concluded that there is insufficient evidence to support the use of albumin in LVP, although the authors did not specify if an alternative agent could be superior to albumin. ${ }^{77}$ In addition, the focus on HCC-free patients in this analysis reduced the overall sample size and thus the likelihood of detecting a significant difference with regards to mortality. ${ }^{85}$ Furthermore, the recently published Cochrane review on the use of plasma expanders following paracentesis concluded that there is insufficient evidence to prove or disprove their benefits in this setting ${ }^{78}$ contrary to current guidelines. $^{21,22}$ The authors assessed 27 RCTs but found that because the evidence was deemed to be of very low certainty, the effects of plasma expanders on all-cause mortality, renal impairment and adverse event rates were inconclusive. The authors could neither demonstrate nor disprove any benefit of plasma expansion vs no plasma expansion, or of one plasma expander vs another.

Other studies have evaluated the use of mannitol as an alternative to albumin infusion for plasma expansion. ${ }^{55}$ Despite mannitol having some efficacy for the prevention of renal failure, it is not indicated for the treatment of cirrhosis and the long-term effects of mannitol in this setting, particularly in patients with pre-existing renal dysfunction, are currently unknown.

\section{Is Albumin Better Than Vasoconstrictors in Preventing PICD?}

Vasoconstrictors such as terlipressin, midodrine and noradrenaline have been proposed as alternatives to albumin for the prevention of PICD. The rationale for using vasoconstrictors is to improve circulatory dysfunction by increasing arterial pressure; however, at least 3 days of treatment with terlipressin are required to improve renal function. ${ }^{21}$ The efficacy of terlipressin alone (without albumin infusion) to prevent PICD has been investigated, and patients were found to have a similar response to treatment in the terlipressin (total dose of $3 \mathrm{mg}$ administered as an intravenous bolus of $1 \mathrm{mg}$ at the onset of paracentesis repeated after 8 and 16 hours) and albumin groups. ${ }^{54,66}$ The meta-analysis by Kutting et al found that albumin was significantly more effective than vasoconstrictive agents at reducing hyponatremia and demonstrated a trend towards reduced mortality in patients who received albumin, although this was not statistically significant. ${ }^{77}$ Midodrine (oral midodrine for 2 days, or oral midodrine for 30 days after LVP or adjusted to maintain mean arterial pressure $10 \mathrm{mmHg}$ above baseline for 72 hours) has also been proposed to have comparable efficacy with albumin for the prevention PICD, with potential cost-saving opportunities. ${ }^{44,64}$ However, midodrine (12.5 $\mathrm{mg}$ three time per day over three days) may not be as effective as albumin at decreasing/preventing PICD following $\mathrm{LVP}^{46}$ especially in patients with HCC $^{39}$ A recent meta-analysis by Guo et al $(\mathrm{N}=462)$ 
reported that midodrine did not improve survival in patients with cirrhotic ascites and was associated with increased mortality when used as an alternative to albumin in LVP, though no statistically significant difference in the development of PICD was detected. ${ }^{74}$ The combination of the vasoconstrictors midodrine (10 $\mathrm{mg}$ three times a day) plus octreotide (20 micrograms) administered every month following LVP did not show a superior effect when compared with albumin administration as patients developed recurrent ascites in a shorter time and had worse outcomes overall. $^{27}$ Finally, other vasoconstrictors, such as noradrenaline (titrated to maintain mean arterial pressure 10 $\mathrm{mmHg}$ above baseline; maximum dose $3 \mathrm{mg} /$ hour), have been investigated and proposed to be as effective as albumin in the prevention of PICD. ${ }^{48}$

Renal Dysfunction, Including Hepatorenal Syndrome (HRS), Induced by Spontaneous Bacterial Peritonitis (SBP)

SBP is a life-threatening complication of cirrhosis. As the most common predictor of SBP-related mortality is the development of renal dysfunction, ${ }^{79}$ its prevention is crucial.

\section{Is Albumin Useful for SBP?}

Sort et al showed that patients with cirrhosis and SBP receiving cefotaxime plus albumin $(1.5 \mathrm{~g} / \mathrm{kg}$ of body weight at diagnosis followed by $1 \mathrm{~g} / \mathrm{kg}$ on day $3 ; \mathrm{N}=63$ ) had a reduced mortality rate compared with patients receiving cefotaxime alone $(\mathrm{N}=63)$; this was true for inpatients $(10 \%$ vs $29 \%)$ and after 3 months of follow-up ( $22 \%$ vs $41 \%) .{ }^{31}$ Patients treated with cefotaxime and albumin also had a lower incidence of renal impairment compared with those treated without additional albumin infusion (10\% vs $33 \%$, respectively). ${ }^{31}$ Similarly, a separate study reported that cefotaxime plus albumin $(\mathrm{N}=56)$ was more effective than cefotaxime alone ( $\mathrm{N}=56)$, with a lower incidence of renal impairment ( $9 \%$ vs 34\%) and lower inhospital mortality ( $9 \%$ vs $30 \%$ ) in patients who received albumin. ${ }^{69}$ In patients with SBP, albumin has demonstrated superior effects on volume expansion and circulatory function when compared with HES, and its effects on peripheral arterial circulation suggest that albumin cannot be replaced by HES in the management of patients with cirrhosis and SBP. ${ }^{50}$ The efficacy of albumin associated with antibiotics at reducing mortality and renal impairment in patients with SBP has been confirmed by a metaanalysis of randomized trials. ${ }^{72}$ A different approach was studied by Salman et al who randomized 200 high risk cirrhotic patients with SBP to receive albumin alone, terlipressin alone, low dose albumin $(10 \mathrm{~g} / 12 \mathrm{~h})$ plus terlipressin or midodrine. ${ }^{37}$ Using terlipressin in combination with low-dose albumin led to a low incidence of renal impairment (8\%) and low in-hospital mortality rate $(6 \%)$, although the findings require validation through further studies.

\section{Renal Dysfunction Induced by Non-SBP Infections}

In this setting, based on available evidence, albumin administration at the same doses as in patients with SBP is not recommended at present. ${ }^{32,38,41}$

\section{Is Albumin Useful in Non-SBP Infections?}

In a randomized study of patients with cirrhosis with infections other than SBP $(\mathrm{N}=110)$, antibiotic treatment plus albumin demonstrated beneficial effects on renal and circulatory function and showed a potential survival benefit compared with antibiotics alone. ${ }^{41}$ In addition, there was a trend for a lower incidence of HRS in patients who received albumin compared with those who did not (1/36 [3\%] vs $4 / 41[10 \%]$ ), although the difference was not statistically significant. A more recent study in patients with cirrhosis and non-SBP infections $(\mathrm{N}=193)$ found that the addition of albumin therapy with antibiotics delayed the onset of renal failure (mean $\pm \mathrm{SD}, 29 \pm 22$ vs $12 \pm 9$ days), but did not improve renal function or survival at 3 months. ${ }^{38}$ However, the investigators acknowledged that they did not use the acute kidney injury (AKI) criteria as these were new and not well recognized or widely established at the time the study was designed. Furthermore, 29 patients (15\%) received unscheduled albumin infusions, including 17 patients $(18 \%)$ in the control group. In $8 / 96$ patients $(8 \%)$ receiving albumin, pulmonary edema was reported and was fatal in two patients. $^{38}$ These results are in contrast to the most recently published RCT evaluating the addition of albumin to antibiotics $(\mathrm{N}=61)$ compared with antibiotic treatment alone $(\mathrm{N}=57)$ for the treatment of patients with cirrhosis and non-SBP-related infections. ${ }^{32}$ In this study, in-hospital mortality was not significantly different between the treatment arms (13.1\% vs $10.5 \%)$; however, patients who received albumin had greater baseline disease severity. Despite this, albumin administration did demonstrate a favorable effect on systemic inflammation within the first 7 days, and the rate of new bacterial infections was significantly lower in patients receiving albumin $(6.6 \%$ vs $24.6 \%)$. In addition, albumin treatment was associated 
with a higher resolution rate of ACLF (82.3\% vs 33.3\%) and reduced need for liver transplantation at 90 days ( 2 vs 6 patients) than seen in the control group.

A meta-analysis of these studies has recently been published. ${ }^{73}$ The 30 and 90 -day mortality rates were not significantly different (risk ratio: 1.62 and 1.27, respectively), and the authors concluded that there is insufficient evidence for the benefit of albumin administration in addition to antibiotics in these patients. Improved renal function in patients receiving albumin was not considered significant. There are, however, several limitations of this analysis, including the small number of clinical trials and low number of patients, which could substantially limit the power to detect a between-group difference.

\section{Treatment of HRS}

HRS is a type of acute kidney injury without an evident renal structure damage that occurs in patients with cirrhosis and portal hypertension. It is associated with high mortality and is often precipitated by bacterial infections. ${ }^{86}$ In this condition, albumin administration is used in combination with vasoconstrictors such as terlipressin, the first-line therapeutic option, or noradrenaline. ${ }^{21}$ After the administration of $1 \mathrm{~g} / \mathrm{kg}$ of body weight (with a maximum of $100 \mathrm{~g}$ ) for two consecutive days for diagnostic purposes, albumin is administered at doses of 20-40 g daily.

\section{Is Albumin Useful in the Treatment of HRS?}

The administration of terlipressin in combination with albumin is recommended as the first-line treatment for HRS $-1^{21}$ and may be effective in $40-50 \%$ of patients. ${ }^{87}$ The beneficial effects of this treatment are associated with the reduction of plasma renin activity and an improvement of arterial pressure, suggesting that the combination of albumin and vasoconstrictors succeeds in improving effective volemia in responder patients. ${ }^{45,47,88}$ Randomized controlled studies shown that albumin plus terlipressin reverse HRS or improve renal function in about $50 \%$ of cases ${ }^{45,47}$ Overall survival was not significantly influenced. However, a survival improvement up to 90 days has been reported in patients who responded to treatment [49]. Cavallin et al found that albumin plus terlipressin were more effective in improving renal function than the combination of albumin, midodrine and octreotide providing a survival advantage in responder patients. ${ }^{65}$ Furthermore, Saif et al found that the administration of terlipressin or noradrenaline in combination with albumin is effective at reversing HRS, and responding patients had a greater survival benefit than nonresponders, potentially extending the time to liver transplantation. ${ }^{36} \mathrm{~A}$ recent meta-analysis that included 1185 patients from 23 trials compared the benefits and harms of common interventions, such as albumin combined with either terlipressin or with noradrenaline, for treating HRS in patients with decompensated cirrhosis. ${ }^{70}$ Patients who received noradrenaline plus albumin had fewer adverse events (rate ratio: 0.51), and those who received terlipressin plus albumin had improved HRS recovery compared with midodrine plus octreotide plus albumin or octreotide plus albumin. While the included evidence was judged to be of very low certainty (the studies were generally small, with high dropout rates and varying lengths of follow-up), the analysis does support previous findings and highlights the potential benefits of combining vasoconstrictor drugs with albumin, in patients with HRS. $^{70}$

\section{Are Lower Doses of Albumin Justified and/or Possible?}

Despite recent treatment advances, the dose-response relationship and optimization of albumin regimens have not been fully investigated.

For patients requiring LVP, the recommended albumin dosage is $6-8 \mathrm{~g} / \mathrm{L}$ of ascites removed. ${ }^{21,22,89}$ A pilot study in 70 patients by Alessandria et al investigated the use of half doses $(4 \mathrm{~g} / \mathrm{L})$ of albumin after LVP. ${ }^{43}$ This study indicated that there was no significant difference in the development of PICD and that lower doses are efficacious in the treatment of ascites. Patients in the standard treatment and half-dose treatment groups had similar survival rates at 6 months, suggesting that lower doses could potentially help to reduce treatment-related costs without compromising efficacy. However, this pilot study was underpowered to establish the equivalence of the two albumin doses assessed. Further to this, the Chinese Medical Association (CMA) guidelines ${ }^{89}$ recommend $4 \mathrm{~g} / \mathrm{L}$ of albumin infused for $\geq 4 \mathrm{~L}$ of ascitic fluid removed during LVP, suggesting that further investigation into lower doses of albumin may be justified. An alternative approach that has been proposed is reinfusion of filtered ascitic fluid, with the aim of reducing the associated cost of using albumin. However, significant allergic reactions caused by the reinfused ascitic acid, as well as costs associated with appropriate filtration, mean that this procedure cannot be considered as an alternative to albumin therapy in LVP. ${ }^{58,67}$ 
In patients with SBP, treatment with albumin was particularly effective in patients with baseline serum bilirubin $\geq 4 \mathrm{mg} / \mathrm{dl}$ or serum creatinine $\geq 1 \mathrm{mg} / \mathrm{dl}^{31}$ As the occurrence of renal dysfunction in patients with baseline bilirubin $<4 \mathrm{mg} / \mathrm{dl}$ and serum creatinine $<1 \mathrm{mg} / \mathrm{dl}$ was very low, it is unclear whether these patients would also benefit from albumin administration, as prospective randomized studies addressing this matter are lacking.

A meta-analysis by Salerno et al found that cumulative albumin doses in increments of $100 \mathrm{~g}$ were associated with a significant increase in survival in patients with HRS-1. ${ }^{76}$ Of the 377 pooled patients, the predicted survival at 30 days was $43.2 \%, 51.4 \%$ and $59.0 \%$ in those patients receiving 200, 400 and $600 \mathrm{~g}$ of albumin, respectively.

\section{Long-Term Albumin Administration in Decompensated Cirrhosis}

The effect of long-term albumin administration in patients with decompensated cirrhosis has also been studied. In addition to better control of ascites, ${ }^{33-35}$ it appears that this treatment also reduces the development of complications such as renal dysfunction, hyponatremia, HRS, HE, SPB, and non-SBP bacterial infections. Long-term albumin administration was also shown to reduce the need for hospitalization $^{33,90}$ and improve survival. ${ }^{33,34,90}$ Thus, long-term albumin administration in patients with decompensated cirrhosis may be classed as a disease-modifying therapy. However, few studies have assessed the long-term benefits of albumin administration and the favorable evidence has been challenged. ${ }^{91}$

\section{Is Long-Term Albumin Administration Useful in Decompensated Cirrhosis?}

The impact of albumin administration on long-term survival in patients with cirrhosis has not been extensively studied. The first long-term randomized trial, published in 1999, evaluated the addition of albumin to diuretic treatment to relieve ascites in patients with cirrhosis $(\mathrm{N}=126) .{ }^{35}$ The recurrence of ascites and subsequent hospital re-admissions were reduced in patients receiving albumin infusions at $25 \mathrm{~g}$ per week for the first year and $25 \mathrm{~g}$ twice weekly for the following two years. However, there was no significant difference between patients receiving diuretics alone and patients receiving diuretics plus albumin with respect to survival and the incidence of other complications. In 2006, a follow-up study evaluating patients with ascites $(\mathrm{N}=100)$ for a median of 84 months showed that patients receiving albumin and diuretics did have a significantly greater survival rate compared with those receiving diuretics alone (median cumulative survival rate of 108 months vs 36 months respectively, $\mathrm{p}=0.0079){ }^{34}$

The ANSWER (human albumin for the treatment of ascites in patients with hepatic cirrhosis) trial, published in 2018, was the first high-powered prospective study of longterm albumin administration in cirrhosis. ${ }^{33}$ ANSWER included 431 patients with cirrhosis and compared albumin with standard medical treatment (SMT) for the management of ascites for up to 18 months. Albumin ( $40 \mathrm{~g}$ twice weekly for 2 weeks followed by $40 \mathrm{~g}$ weekly in combination with SMT) was associated with a significant increase in serum albumin concentration from a baseline of $3.1 \mathrm{~g} / \mathrm{dL}$ to $\sim 4.0 \mathrm{~g} /$ $\mathrm{dL}$ within 2 months. Albumin in combination with SMT was shown to act as a disease-modifying treatment and prolonged overall survival, with a $38 \%$ reduction in the mortality hazard ratio compared with SMT alone. In addition, long-term weekly albumin administration reduced the need of paracentesis and the incidence of complications, such as renal dysfunction, HRS, bacterial infections, severe HE, hyponatremia and hyperkalemia, and related hospitalizations. It also improved patient quality of life, and may provide a costsaving opportunity. ${ }^{33}$ In fact, the extra costs related to the use of albumin in addition to SMT were counterbalanced by savings made with regards to reduced hospital admissions and reduced albumin use for other conditions, eg PICD. The incremental cost-effectiveness ratio was $€ 21,265$ per qualityadjusted life year, which is well within the defined thresholds for cost-effectiveness. ${ }^{92}$

A post hoc analysis of the ANSWER study examined whether serum albumin achieved during treatment was associated with survival and complications (citation not included in the assessment of bias as not the primary ANSWER manuscript). ${ }^{93}$ This established that the probability of 18-month survival improved in parallel with increasing serum albumin levels at 1 month. The survival benefit continued to improve with increasing serum albumin at 1 month, even beyond the lower normal limit $(\geq 3.5$ $\mathrm{g} / \mathrm{dL}$ ). There was an $80 \%$ decrease in mortality in patients with serum albumin of $4.0 \mathrm{~g} / \mathrm{dL}$ compared with patients below that threshold. Therefore, serum albumin of $4.0 \mathrm{~g} /$ $\mathrm{dL}$ at 1 month may be a suitable on-treatment target to ensure optimal clinical outcomes. However, patients who did not reach serum albumin of $4.0 \mathrm{~g} / \mathrm{dL}$ still benefitted from long-term albumin and survival with albumin plus SMT was significantly higher than with SMT alone, even in patients with serum albumin below normal $(<3.5 \mathrm{~g} / \mathrm{dL})$ at 1 month. 
Long-term albumin administration was well tolerated. The incidence of variceal bleeding did not differ between the two arms of the study, showing that plasma volume expansion induced by the albumin dose employed in the study did not increase portal hypertension. Among the 218 patients who received albumin, only 2 patients developed mild and transient allergic reactions, one developed transient hypotension associated with dizziness, and 2 developed sepsis, which resolved with treatment. However, the link between albumin administration and sepsis is doubtful.

On the contrary, the main findings of the ANSWER study, namely improved survival and reduced incidence of complications, were not confirmed by the MACHT study, a prospective, randomized placebo-controlled study that enrolled patients with decompensated cirrhosis awaiting liver transplantation $(\mathrm{N}=196) .{ }^{25}$ In this trial, patients included in the active arm of the study received longterm midodrine plus albumin ( $40 \mathrm{~g}$ every 15 days; median duration 80 days), while the control group received SMT plus placebos. There were no significant differences between the groups in the rates of complications of cirrhosis or survival. It should be noted that the median patient follow-up was 80 days, due to a high rate of transplantation. Furthermore, the albumin dose used was about half that used in the ANSWER study, and a loading dose was not given. As a result, whereas in the ANSWER study serum albumin concentration increased significantly within a month and remained steady thereafter, it did not undergo any significant change in the MACHT study.

\section{Discussion}

Clinical consensus has evolved over the last decade and it is now widely accepted that in patients with cirrhosis who develop ascites, LVP is performed with an adjunctive therapy to reduce the risk of PICD. This systematic review suggests that albumin is a good alternative to any other volume expander or vasoconstrictor that has been evaluated for the prevention of PICD, and studies have demonstrated a survival benefit with albumin. ${ }^{33,34,90}$

Selecting the appropriate fluid solution has been widely debated, and alternative therapies are not well-established and require further evaluation before they can be recommended in current practice. ${ }^{84}$ Some alternative therapies evaluated in this review, such as gelatin, are no longer used, while dextran is rarely used due to the risk of severe allergic reactions and renal failure previously observed. ${ }^{21}$ The administration of saline may be justified as a cheaper alternative to albumin in some cases, particularly if $<5 \mathrm{~L}$ of ascitic fluid is removed during paracentesis. ${ }^{52}$ However, alternative plasma expanders are not recommended by the EASL and the Italian Association for the Study of Liver and the Italian Society of Transfusion Medicine and Immunohaematology (AISF-SIMTI) if $>5$ L of ascites are removed. ${ }^{21,94}$ Although mannitol produces transient volume expansion, it is neither indicated for use as a volume expander nor recognized as an adjunctive treatment option after LVP. The study by Zhao et $\mathrm{al}^{55}$ identified in this review is the only clinical trial indexed in PubMed that evaluates mannitol in patients with cirrhosis. Furthermore, large trials have shown that HES increases the risk of mortality, AKI and bleeding when used for plasma expansion. ${ }^{95-97}$ This prompted two calls for the removal of HES from the European market during the last six years, ${ }^{98-100}$ and the FDA issued a "black box" warning in 2013. ${ }^{101}$ Thus, HES administration should be avoided in patients with cirrhosis and ascites, who frequently show renal dysfunction and are at risk of developing AKI. A recent Cochrane review cast doubts about the superiority of albumin in preventing PICD with respect to other plasma expanders. ${ }^{78}$ This is unsurprising given the high degree of heterogeneity between the included studies and that none was designed specifically to evaluate mortality. As a result, the authors suggested that use of a plasma expander after LVP should be based on physician and patient preference. This would lead, once more, to the use of albumin, considering the indications of the current international guidelines, ${ }^{21,22}$ and the side-effects of artificial plasma expanders discussed above.

The vasoconstrictors midodrine and terlipressin have been evaluated as alternatives to albumin to prevent PICD as they may counteract the worsening of effective volemia that underlies the development of this complication. ${ }^{81}$ Some studies claimed that these drugs are as effective as albumin. ${ }^{39,44,46,48,49,54,59-61,66,68,74}$ However, they were underpowered to warrant equivalence and, therefore, vasoconstrictors cannot be recommended in clinical practice at present. Thus, based on the current evidence, national and international guidelines recommend the use of albumin (6-8 $\mathrm{g} / \mathrm{L}$ of ascites removed) to prevent PICD (Table 5). ${ }^{21,22,94}$

Despite the cost of albumin having decreased relative to other products over the last 10 years, ${ }^{102}$ albumin use to prevent PICD is often deemed to be highly expensive. Thus, it has been assessed whether prevention could be ensured by lower doses ( $4 \mathrm{~g} / \mathrm{L}$ of ascites removed). ${ }^{43}$ Even 
though similar results were obtained with respect to $8 \mathrm{~g} / \mathrm{L}$, this study was also underpowered to warrant equivalence. Furthermore, albumin appeared to be more cost-effective than gelatin because of the lower number of liver-related complications and hospital costs. ${ }^{49}$

Bacterial infections represent an ominous complication in patients with cirrhosis and ascites, due to the frequent development of renal impairment and high mortality. Albumin has been used to prevent these events. Its efficacy in preventing renal dysfunction and AKI and improving survival has been convincingly demonstrated in SBP. ${ }^{31}$ However, it is still undefined whether this prophylactic treatment should be limited to patients at high risk of complications and death. Preventive albumin use in patients with bacterial infections other than SBP does not appear to improve survival, ${ }^{32,38}$ and further studies are warranted in this setting.

The combined administration of albumin and terlipressin or noradrenaline represents the current standard of care in treating HRS, ${ }^{21,94}$ based on prospective randomized clinical trials. ${ }^{36,47}$ Due to the difficulty to recruit such critically ill patients into clinical trials, the available studies enrolled patient numbers too low to achieve full statistical power in assessing survival. However, the beneficial effects of this treatment have been confirmed by a meta-analysis showing that terlipressin used in combination with albumin prolongs short-term survival in patients with $\mathrm{HRS}^{103}$ It is worth noting that a nonrandomized trial showed that terlipressin plus albumin is more effective than terlipressin alone in patients with HRS. $^{88}$

Advancements in the knowledge of the pathophysiological background underlying the manifestations of decompensated cirrhosis, in particular the demonstration of the sustained pro-inflammatory and pro-oxidant state that characterize these patients, ${ }^{8}$ has opened up the perspective of the long-term use of drugs able to counteract such abnormalities as disease-modifying agents. ${ }^{10}$ Prevention of complications and improved survival represent the highly relevant effects that could be expected. Albumin can be included among these agents, due to its pleiotropic non-oncotic effects. ${ }^{13}$ Available studies, including the core results of the ANSWER trial ${ }^{33}$ and a recent non-randomized prospective study, which employed a similar albumin weekly dose ( $20 \mathrm{~g}$ twice a week), ${ }^{90}$ have shown that long-term albumin administration eases the control of ascites, ${ }^{33-35}$ prevents the occurrence of refractory ascites ${ }^{33}$ and severe complications of cirrhosis, ${ }^{33,90}$ and also improves survival. ${ }^{33,34,90}$ Other relevant findings were an improvement in patient quality of life and a reduction in hospitalizations, such that, ultimately, long-term albumin administration was cost-effective. ${ }^{33}$

It has to be considered, however, that variant results have been published, as the MACHT study, a placebocontrolled trial comparing the administration of albumin plus midodrine with SMT alone in patients with decompensated cirrhosis awaiting liver transplantation, did not confirm such beneficial effects. ${ }^{25}$ Comparing the designs of the ANSWER and MACHT studies can explain the reasons for their conflicting results and provide lessons about long-term albumin administration ${ }^{104}$. The two studies differed substantially in the length of patient follow-up and amount of albumin administered. Thus, it appears that long-term albumin administration should succeed in steadily increasing serum albumin concentration for a sufficient time frame to obtain beneficial effects. The importance of on-treatment serum albumin concentration has been emphasized by the results of a post hoc analysis of the ANSWER database, showing that albuminemia at month 1 of treatment predicts survival, which increases in parallel with serum albumin concentration. ${ }^{93}$

It is worth noting that available studies on long-term albumin administration did not report an increased incidence of gastrointestinal bleeding secondary to portal hypertension. ${ }^{25,33-35,90}$ This is relevant, as anecdotal studies performed in the 1940s and the early 1960s warned about the risk of variceal bleeding after repeated albumin administration in patients with cirrhosis and ascites. ${ }^{105,106}$ It should be noted that those studies employed a considerably larger amount of albumin (up to 100 $\mathrm{g}$ daily for several days) than did the more recent controlled randomized trials.

Additional clinical trials assessing the role of long-term albumin administration in patients with decompensated cirrhosis are ongoing. The PRECIOSA study, ${ }^{80}$ which is comparing the long-term use of albumin with SMT, aims to ascertain the prevalence of 1-year mortality and the development of ACLF. The results of a pilot-PRECIOSA dose-finding study showed that long-term (12 weeks) high-dose albumin (1.5 g/kg of body weight/week), but not the dose of $1 \mathrm{~g} / \mathrm{kg}$ body weight every 2 weeks, normalized serum albumin concentration and reduced systemic inflammation and cardiovascular dysfunction in patients 
Table 5 Clinical Recommendations for the Use of Albumin to Treat Complications in Patients with Cirrhosis

\begin{tabular}{|c|c|c|c|c|}
\hline Uses & EASL $2018^{21}$ & AASLD $2012^{22}$ & AISF-SIMTI $2016^{94}$ & CMA $2019^{89}$ \\
\hline PICD & $\begin{array}{l}\text { If } \geq 5 \mathrm{~L} \text { ascites removed, } \\
\text { infuse } 8 \mathrm{~g} / \mathrm{L} \text { albumin } \\
\text { If } \leq 5 \mathrm{~L} \text { ascites removed, } \\
\text { infuse albumin* }\end{array}$ & $\begin{array}{l}\text { If } \geq 5 \mathrm{~L} \text { ascites removed, infuse } 6-8 \mathrm{~g} / \mathrm{L} \\
\text { albumin } \\
\text { If } \leq 5 \mathrm{~L} \text { ascites removed, albumin } \\
\text { infusion may not be necessary }\end{array}$ & $\begin{array}{l}\text { If } \geq 5 \mathrm{~L} \text { ascites removed, infuse } \\
6-8 \mathrm{~g} / \mathrm{L} \text { albumin } \\
\text { If } \leq 5 \mathrm{~L} \text { ascites removed, albumin } \\
\text { infusion preferred due to } \\
\text { concerns regarding the use of } \\
\text { synthetic colloids/crystalloids* }\end{array}$ & $\begin{array}{l}\text { If } \geq 4 \mathrm{~L} \text { ascites } \\
\text { removed, infuse } 4 \mathrm{~g} / \\
\mathrm{L} \text { albumin }\end{array}$ \\
\hline SBP & $\begin{array}{l}\text { Day I: I.5 g/kg albumin, } \\
\text { Day 3: I g/kg (in } \\
\text { combination with broad } \\
\text { spectrum antibiotics) }\end{array}$ & $\begin{array}{l}\text { Day I: Cefotaxime plus } 1.5 \mathrm{~g} / \mathrm{kg} \\
\text { albumin within } 6 \text { hours } \\
\text { Day 3: I } \mathrm{g} / \mathrm{kg} \text { albumin }\end{array}$ & $\begin{array}{l}\text { Day I: } 1.5 \mathrm{~g} / \mathrm{kg} \text { albumin, } \\
\text { Day 3: I } \mathrm{g} / \mathrm{kg} \text { (in combination } \\
\text { with broad spectrum antibiotics) }\end{array}$ & $\begin{array}{l}\text { Insufficient guideline } \\
\text { recommendations }\end{array}$ \\
\hline HRS-I & $\begin{array}{l}\text { Days I-2: I } \mathrm{g} / \mathrm{kg} \text {, then } \\
20-40 \mathrm{~g} / \mathrm{kg} / \text { day in } \\
\text { combination with } \\
\text { terlipressin }(\mathrm{I} \mathrm{mg} / 4-6 \mathrm{~h} \mathrm{IV} \\
\text { bolus) }\end{array}$ & $\begin{array}{l}10-20 \mathrm{~g} / \mathrm{kg} \text { albumin for } 20 \text { days in } \\
\text { combination with vasoactive drugs } 3 \\
\text { times per day (octreotide at } 200 \mu \mathrm{g} \text {; or } \\
\text { midodrine at } 12.5 \mathrm{mg} \text { ) }\end{array}$ & $\begin{array}{l}\text { Days I: I g/kg, then } 20-40 \mathrm{~g} / \mathrm{kg} / \\
\text { day in combination with } \\
\text { vasoconstrictors, until they are } \\
\text { withdrawn }\end{array}$ & $\begin{array}{l}\text { Albumin } 20-40 \mathrm{~g} / \text { day } \\
\text { in combination with } \\
\text { I mg terlipressin } \\
\text { every } 4-6 \mathrm{~h} \text { for } \\
3 \text { days, terlipressin } \\
\text { can be increased to } \\
2 \mathrm{mg} \text { after } 3 \text { days, if } \\
\text { necessary }\end{array}$ \\
\hline $\begin{array}{l}\text { Non-SBP } \\
\text { infections }\end{array}$ & \multicolumn{4}{|c|}{ Insufficient evidence for guideline recommendations } \\
\hline $\begin{array}{l}\text { Long-term } \\
\text { administration }\end{array}$ & \multicolumn{4}{|c|}{$\begin{array}{l}\text { Insufficient evidence for guideline recommendations } \\
\text { Evidence for consideration based on the following trials published after the guidelines: } \\
\text { Albumin at } 40 \mathrm{~g} \text { twice weekly for } 2 \text { weeks, followed by } 40 \mathrm{~g} \text { weekly for a maximum of } 18 \text { months in combination with } \mathrm{SMT}^{33} \\
\text { Albumin at } 20 \mathrm{~g} \text { twice per week in combination with SMT for up to } 24 \text { months }\end{array}$} \\
\hline
\end{tabular}

Note: *Dose not defined.

Abbreviations: AASLD, American Association for the Study of Liver Diseases. AISF-SIMTI, Italian Association for the Study of Liver and the Italian Society of Transfusion Medicine and Immunohaematology; CMA, Chinese Medical Association; EASL, European Association for the Study of Liver; h, hour; HRS-I, hepatorenal syndrome type-I; PICD, paracentesis-induced circulatory dysfunction; SBP, spontaneous bacterial peritonitis, SMT, standard medical treatment.

with decompensated cirrhosis; however, only 18 patients were enrolled in the study. ${ }^{80}$

\section{Conclusions}

The findings from this systematic review support the increased utilization of albumin for the treatment or prevention of complications arising from cirrhosis. In patients with decompensated cirrhosis, a clinical benefit including enhanced survival is apparent following the administration of albumin alone or in combination with other treatments (such as antibiotics or vasoconstrictors) to prevent PICD and renal dysfunction induced by SBP, and to treat HRS. Thus, this review fully supports the EASL and AASLD recommendations for the management of patients with decompensated cirrhosis. Longterm albumin administration may become a standard of care in these patients as it appears to favorably influence the course of the disease.

\section{Abbreviations}

ACLF, acute on chronic liver failure; AASLD, American Association for the Study of Liver Diseases; CI, confidence interval; CMA, Chinese Medical Association; EASL, European Association for the Study of the Liver; HCC, hepatocellular carcinoma; HE, hepatic encephalopathy; HES, hydroxyethyl starch; HRS, hepatorenal syndrome; LVP, large volume paracentesis; OR, odds ratio; PICD, paracentesis-induced circulatory dysfunction; PRISMA, Preferred Reporting Items for Systematic Reviews and MetaAnalyses; RCTs, randomized controlled trials; SBP, spontaneous bacterial peritonitis; SIGN, Scottish Intercollegiate Guidelines Network; SMT, standard medical treatment.

\section{Acknowledgments}

Medical writing assistance was provided by Meridian HealthComms Ltd in accordance with good publication practice (GPP3), funded by CSL Behring. 


\section{Author Contributions}

All authors made substantial contributions to conception and design, acquisition of data, and analysis; took part in drafting the article; gave final approval of the version to be published; and agree to be accountable for all aspects of the work.

\section{Disclosure}

Dr Giacomo Zaccherini reports being a part of speaker bureau for Octapharma AG and Grifols SA, outside the submitted work. Dr Manuel Tufoni reports personal fees from Grifols SA and Octapharma AG, outside the submitted work; Grifols SA (speaker bureau). Professor Mauro Bernardi reports personal fees from Grifols SA, Shire/Takeda, CLS Behring GmbH, PPTA, Martin Pharmaceuticals, and Octapharma $\mathrm{AG}$, during the conduct of the study; CSL Behring GmbH (consultant, speaker bureau), Grifols SA (consultant, speaker bureau), Takeda (speaker bureau), PPTA (speaker bureau), Octapharma AG (speaker bureau), Martin Pharmaceuticals (consultant). The authors report no other potential conflicts of interest for this work.

\section{References}

1. Tsochatzis EA, Bosch J, Burroughs AK. Liver cirrhosis. Lancet. 2014;383(9930):1749-1761. doi:10.1016/S0140-6736(14)60121-5

2. Gines P, Quintero E, Arroyo V, et al. Compensated cirrhosis: natural history and prognostic factors. Hepatology. 1987;7 (1):122-128. doi:10.1002/hep.1840070124

3. D'Amico G, Garcia-Tsao G, Pagliaro L. Natural history and prognostic indicators of survival in cirrhosis: a systematic review of 118 studies. J Hepatol. 2006;44(1):217-231. doi:10.1016/j.jhep.2005.10.013

4. Moore KP, Aithal GP. Guidelines on the management of ascites in cirrhosis. Gut. 2006;55(Suppl 6):vi1-12. doi:10.1136/gut.2006.099 580

5. Moreau R, Jalan R, Gines P, et al. Acute-on-chronic liver failure is a distinct syndrome that develops in patients with acute decompensation of cirrhosis. Gastroenterology. 2013;144(7):1426-1437, 1437 e1421-1429. doi:10.1053/j.gastro.2013.02.042

6. Arroyo V. Acute-on-chronic liver failure in cirrhosis requires expedited decisions for liver transplantation. Gastroenterology. 2019;156(5):1248-1249. doi:10.1053/j.gastro.2019.03.004

7. Jalan R, Fernandez J, Wiest R, et al. Bacterial infections in cirrhosis: a position statement based on the EASL special conference 2013. J Hepatol. 2014;60(6):1310-1324. doi:10.1016/j.jhep.2014. 01.024

8. Bernardi M, Moreau R, Angeli P, Schnabl B, Arroyo V. Mechanisms of decompensation and organ failure in cirrhosis: from peripheral arterial vasodilation to systemic inflammation hypothesis. $J$ Hepatol. 2015;63(5):1272-1284. doi:10.1016/j. jhep.2015.07.004

9. Schrier RW, Arroyo V, Bernardi M, Epstein M, Henriksen JH, Rodes J. Peripheral arterial vasodilation hypothesis: a proposal for the initiation of renal sodium and water retention in cirrhosis. Hepatology. 1988;8(5):1151-1157. doi:10.1002/hep.1840080532

10. Bernardi M, Caraceni P. Novel perspectives in the management of decompensated cirrhosis. Nat Rev Gastroenterol Hepatol. 2018;15 (12):753-764. doi:10.1038/s41575-018-0045-2
11. Quinlan GJ, Martin GS, Evans TW. Albumin: biochemical properties and therapeutic potential. Hepatology. 2005;41(6):1211-1219. doi:10.1002/hep.20720

12. Caraceni P, Tufoni M, Bonavita ME. Clinical use of albumin. Blood Transfus. 2013;11(Suppl 4):s18-25.

13. Garcia-Martinez R, Caraceni P, Bernardi M, Gines P, Arroyo V, Jalan R. Albumin: pathophysiologic basis of its role in the treatment of cirrhosis and its complications. Hepatology. 2013;58 (5):1836-1846. doi:10.1002/hep.26338

14. Henriksen JH, Siemssen O, Krintel JJ, Malchow-Moller A, Bendtsen F, Ring-Larsen H. Dynamics of albumin in plasma and ascitic fluid in patients with cirrhosis. J Hepatol. 2001;34(1):53-60. doi:10.1016/S0168-8278(00)00009-X

15. Salerno F, Borroni G, Moser P, et al. Survival and prognostic factors of cirrhotic patients with ascites: a study of 134 outpatients. Am J Gastroenterol. 1993;88(4):514-519.

16. Oettl K, Birner-Gruenberger R, Spindelboeck W, et al. Oxidative albumin damage in chronic liver failure: relation to albumin binding capacity, liver dysfunction and survival. J Hepatol. 2013;59 (5):978-983. doi:10.1016/j.jhep.2013.06.013

17. Domenicali M, Baldassarre M, Giannone FA, et al. Posttranscriptional changes of serum albumin: clinical and prognostic significance in hospitalized patients with cirrhosis. Hepatology. 2014;60(6):1851-1860. doi:10.1002/hep.27322

18. Baldassarre M, Domenicali M, Naldi M, et al. Albumin homodimers in patients with cirrhosis: clinical and prognostic relevance of a novel identified structural alteration of the molecule. Sci Rep. 2016;6:35987. doi:10.1038/srep35987

19. Jalan R, Schnurr K, Mookerjee RP, et al. Alterations in the functional capacity of albumin in patients with decompensated cirrhosis is associated with increased mortality. Hepatology. 2009;50 (2):555-564. doi:10.1002/hep.22913

20. Giannone FA, Domenicali M, Baldassarre M, et al. Ischaemiamodified albumin: a marker of bacterial infection in hospitalized patients with cirrhosis. Liver Int. 2015;35(11):2425-2432. doi:10.1111/liv.12860

21. European Association for the Study of the Liver. Electronic address eee, European Association for the Study of the L. EASL Clinical Practice Guidelines for the management of patients with decompensated cirrhosis. J Hepatol. 2018;69(2):406-460. doi:10.1016/j. jhep.2018.03.024

22. American Association for the Study of Liver Diseases. Practice guideline: management of adult patients with ascites due to cirrhosis: update 2012; 2013. Available from: https://www.aasld.org/sites/default/files/ 2019-06/AASLDPracticeGuidelineAsciteDuetoCirrhosis Update2012Edition4_.pdf. Accessed May 2020.

23. Moher D, Liberati A, Tetzlaff J, Altman DG, Group P. Preferred reporting items for systematic reviews and meta-analyses: the PRISMA statement. Ann Intern Med. 2009;151(4):264-269, W264. doi:10.7326/0003-4819-151-4-200908180-00135

24. Scottish Intercollegiate Guidelines Network (SIGN). SIGN GRADING SYSTEM 1999 - 2012. Available from: https://www. sign.ac.uk/assets/sign_grading_system_1999_2012.pdf. Accessed May 2020. 2012.

25. Sola E, Sole C, Simon-Talero M, et al. Midodrine and albumin for prevention of complications in patients with cirrhosis awaiting liver transplantation. A randomized placebo-controlled trial. J Hepatol. 2018;69(6):1250-1259. doi:10.1016/j.jhep.2018.08.006

26. Boyer TD, Sanyal AJ, Wong F, et al. Terlipressin plus albumin is more effective than albumin alone in improving renal function in patients with cirrhosis and hepatorenal syndrome Type 1. Gastroenterology. 2016;150(7):1579-1589. doi:10.1053/j.gastro.2016.02.026

27. Bari K, Minano C, Shea M, et al. The combination of octreotide and midodrine is not superior to albumin in preventing recurrence of ascites after large-volume paracentesis. Clin Gastroenterol Hepatol. 2012;10(10):1169-1175. doi:10.1016/j.cgh.2012.06.027 
28. Gines P, Arroyo V, Quintero E, et al. Comparison of paracentesis and diuretics in the treatment of cirrhotics with tense ascites. Results of a randomized study. Gastroenterology. 1987;93 (2):234-241. doi:10.1016/0016-5085(87)91007-9

29. Gines P, Tito L, Arroyo V, et al. Randomized comparative study of therapeutic paracentesis with and without intravenous albumin in cirrhosis. Gastroenterology. 1988;94(6):1493-1502. doi:10.1016/ 0016-5085(88)90691-9

30. Gines A, Fernandez-Esparrach G, Monescillo A, et al. Randomized trial comparing albumin, dextran 70 , and polygeline in cirrhotic patients with ascites treated by paracentesis. Gastroenterology. 1996;111(4):1002-1010. doi:10.1016/S0016-5085(96)70068-9

31. Sort P, Navasa M, Arroyo V, et al. Effect of intravenous albumin on renal impairment and mortality in patients with cirrhosis and spontaneous bacterial peritonitis. $N$ Engl J Med. 1999;341(6):403-409. doi:10.1056/NEJM199908053410603

32. Fernandez J, Angeli P, Trebicka J, et al. Efficacy of albumin treatment for patients with cirrhosis and infections unrelated to spontaneous bacterial peritonitis. Clin Gastroenterol Hepatol. 2020;18(4):963-973e914. doi:10.1016/j.cgh.2019.07.055

33. Caraceni P, Riggio O, Angeli P, et al. Long-term albumin administration in decompensated cirrhosis (ANSWER): an open-label randomised trial. Lancet. 2018;391(10138):2417-2429. doi:10.1016/ S0140-6736(18)30840-7

34. Romanelli RG, La Villa G, Barletta G, et al. Long-term albumin infusion improves survival in patients with cirrhosis and ascites: an unblinded randomized trial. World $J$ Gastroenterol. 2006;12 (9):1403-1407. doi:10.3748/wjg.v12.i9.1403

35. Gentilini P, Casini-Raggi V, Di Fiore G, et al. Albumin improves the response to diuretics in patients with cirrhosis and ascites: results of a randomized, controlled trial. J Hepatol. 1999;30 (4):639-645. doi:10.1016/S0168-8278(99)80194-9

36. Saif RU, Dar HA, Sofi SM, Andrabi MS, Javid G, Zargar SA. Noradrenaline versus terlipressin in the management of type 1 hepatorenal syndrome: a randomized controlled study. Ind $J$ Gastroenterol. 2018;37(5):424-429. doi:10.1007/s12664-018-0876-3

37. Salman TA, Edrees AM, El-Said HH, El-Abd OL, El-Azab GI. Effect of different therapeutic modalities on systemic, renal, and hepatic hemodynamics and short-term outcomes in cirrhotic patients with spontaneous bacterial peritonitis. Eur $J$ Gastroenterol Hepatol. 2016;28(7):777-785. doi:10.1097/MEG.0000000000000635

38. Thevenot T, Bureau C, Oberti F, et al. Effect of albumin in cirrhotic patients with infection other than spontaneous bacterial peritonitis. A randomized trial. J Hepatol. 2015;62(4):822-830. doi:10.1016/j. jhep.2014.11.017

39. Hamdy H, ElBaz AA, Hassan A, Hassanin O. Comparison of midodrine and albumin in the prevention of paracentesis-induced circulatory dysfunction in cirrhotic patients: a randomized pilot study. J Clin Gastroenterol. 2014;48(2):184-188. doi:10.1097/ MCG.0b013e31829ae376

40. Simon-Talero M, Garcia-Martinez R, Torrens M, et al. Effects of intravenous albumin in patients with cirrhosis and episodic hepatic encephalopathy: a randomized double-blind study. J Hepatol. 2013;59(6):1184-1192. doi:10.1016/j.jhep.2013.07.020

41. Guevara M, Terra C, Nazar A, et al. Albumin for bacterial infections other than spontaneous bacterial peritonitis in cirrhosis. A randomized, controlled study. J Hepatol. 2012;57(4):759-765. doi:10.1016/j.jhep.2012.06.013

42. Yang J, Wang WT, Yan LN, Xu MQ, Yang JY. Alternatives to albumin administration in hepatocellular carcinoma patients undergoing hepatectomy: an open, randomized clinical trial of efficacy and safety. Chin Med J. 2011;124(10):1458-1464.

43. Alessandria C, Elia C, Mezzabotta L, et al. Prevention of paracentesis-induced circulatory dysfunction in cirrhosis: standard vs half albumin doses. A prospective, randomized, unblinded pilot study. Digest Liver Dis. 2011;43(11):881-886.
44. Singh V, Dheerendra PC, Singh B, et al. Midodrine versus albumin in the prevention of paracentesis-induced circulatory dysfunction in cirrhotics: a randomized pilot study. Am J Gastroenterol. 2008;103 (6):1399-1405.

45. Sanyal AJ, Boyer T, Garcia-Tsao G, et al. A randomized, prospective, double-blind, placebo-controlled trial of terlipressin for type 1 hepatorenal syndrome. Gastroenterology. 2008;134(5):1360-1368. doi:10.1053/j.gastro.2008.02.014

46. Appenrodt B, Wolf A, Grunhage F, et al. Prevention of paracentesis-induced circulatory dysfunction: midodrine vs albumin. A randomized pilot study. Liver Int. 2008;28(7):1019-1025. doi:10.1111/j.1478-3231.2008.01734.x

47. Martin-Llahi M, Pepin MN, Guevara M, et al. Terlipressin and albumin vs albumin in patients with cirrhosis and hepatorenal syndrome: a randomized study. Gastroenterology. 2008;134(5):1352-1359.

48. Singh V, Kumar B, Nain CK, et al. Noradrenaline and albumin in paracentesis-induced circulatory dysfunction in cirrhosis: a randomized pilot study. $J$ Intern Med. 2006;260(1):62-68. doi:10.1111/j.1365-2796.2006.01654.x

49. Moreau R, Valla DC, Durand-Zaleski I, et al. Comparison of outcome in patients with cirrhosis and ascites following treatment with albumin or a synthetic colloid: a randomised controlled pilot trail. Liver Int. 2006;26(1):46-54. doi:10.1111/j.1478-3231.2005.01188.x

50. Fernandez J, Monteagudo J, Bargallo X, et al. A randomized unblinded pilot study comparing albumin versus hydroxyethyl starch in spontaneous bacterial peritonitis. Hepatology. 2005;42 (3):627-634. doi:10.1002/hep.20829

51. Degoricija V, Zjacic-Rotkvic V, Marout J, Sefer S, Troskot B. Clinical and neurohumoral response to posture, physical exercise, and ascites treatment in Child-Pugh $\mathrm{C}$ liver cirrhosis: randomized prospective trial. Croat Med J. 2003;44(2):178-186.

52. Sola-Vera J, Minana J, Ricart E, et al. Randomized trial comparing albumin and saline in the prevention of paracentesis-induced circulatory dysfunction in cirrhotic patients with ascites. Hepatology. 2003;37(5):1147-1153. doi:10.1053/jhep.2003.50169

53. Garcia-Compean D, Blanc P, Larrey D, et al. Treatment of cirrhotic tense ascites with Dextran-40 versus albumin associated with large volume paracentesis: a randomized controlled trial. Ann Hepatol. 2002;1(1):29-35. doi:10.1016/S1665-2681(19)32189-1

54. Moreau R, Asselah T, Condat B, et al. Comparison of the effect of terlipressin and albumin on arterial blood volume in patients with cirrhosis and tense ascites treated by paracentesis: a randomised pilot study. Gut. 2002;50(1):90-94. doi:10.1136/gut.50.1.90

55. Zhao J, Yuan C, Wang D, Li X. Mannitolum infusion on cirrhotic patients with tense ascites treated by paracentesis. Chin Med J. 2000;113(1):27-30.

56. Luca A, Garcia-Pagan JC, Bosch J, et al. Beneficial effects of intravenous albumin infusion on the hemodynamic and humoral changes after total paracentesis. Hepatology. 1995;22(3):753-758.

57. Garcia-Compean D, Zacarias Villarreal J, Bahena Cuevas H, et al. Total therapeutic paracentesis (TTP) with and without intravenous albumin in the treatment of cirrhotic tense ascites: a randomized controlled trial. Liver. 1993;13(5):233-238. doi:10.1111/j.16000676.1993.tb00637.x

58. Bruno S, Borzio M, Romagnoni M, et al. Comparison of spontaneous ascites filtration and reinfusion with total paracentesis with intravenous albumin infusion in cirrhotic patients with tense ascites. $B M J$. 1992;304(6843):1655-1658. doi:10.1136/bmj.304.6843.1655

59. Fassio E, Terg R, Landeira G, et al. Paracentesis with Dextran 70 vs. paracentesis with albumin in cirrhosis with tense ascites. Results of a randomized study. J Hepatol. 1992;14(2-3):310-316. doi:10.1016/0168-8278(92)90176-P

60. Salerno F, Badalamenti S, Lorenzano E, Moser P, Incerti P. Randomized comparative study of hemaccel vs. albumin infusion after total paracentesis in cirrhotic patients with refractory ascites. Hepatology. 1991;13(4):707-713. doi:10.1002/hep.1840130416 
61. Planas R, Gines P, Arroyo V, et al. Dextran-70 versus albumin as plasma expanders in cirrhotic patients with tense ascites treated with total paracentesis. Results of a randomized study. Gastroenterology. 1990;99(6):1736-1744. doi:10.1016/0016-5085(90)90481-F

62. Salerno F, Badalamenti S, Incerti P, et al. Repeated paracentesis and i.v. albumin infusion to treat 'tense' ascites in cirrhotic patients. A safe alternative therapy. $J$ Hepatol. 1987;5(1):102-108. doi:10.1016/S0168-8278(87)80067-3

63. Yakar T, Demir M, Dogan O, Parlakgumus A, Ozer B, Serin E. High dose oral furosemide with salt ingestion in the treatment of refractory ascites of liver cirrhosis. Clin Invest Med. 2016;39 (6):27502.

64. Yosry A, Soliman ZA, Eletreby R, Hamza I, Ismail A, Elkady MA. Oral midodrine is comparable to albumin infusion in cirrhotic patients with refractory ascites undergoing large-volume paracentesis: results of a pilot study. Eur J Gastroenterol Hepatol. 2019;31 (3):345-351. doi:10.1097/MEG.0000000000001277

65. Cavallin M, Kamath PS, Merli M, et al. Terlipressin plus albumin versus midodrine and octreotide plus albumin in the treatment of hepatorenal syndrome: A randomized trial. Hepatology. 2015;62 (2):567-574. doi:10.1002/hep.27709

66. Singh V, Kumar R, Nain CK, Singh B, Sharma AK. Terlipressin versus albumin in paracentesis-induced circulatory dysfunction in cirrhosis: a randomized study. J Gastroenterol Hepatol. 2006;21 (1):303-307. doi:10.1111/j.1440-1746.2006.04182.x

67. Zaak D, Paquet KJ, Kuhn R. Prospective study comparing human albumin vs. reinfusion of ultrafiltrate-ascitic fluid after total paracentesis in cirrhotic patients with tense ascites. Z Gastroenterol. 2001;39(1):5-10. doi:10.1055/s-2001-10707

68. Altman C, Bernard B, Roulot D, Vitte RL, Ink O. Randomized comparative multicenter study of hydroxyethyl starch versus albumin as a plasma expander in cirrhotic patients with tense ascites treated with paracentesis. Eur J Gastroenterol Hepatol. 1998;10 (1):5-10. doi:10.1097/00042737-199801000-00002

69. Xue HP, Lin B, Mo JZ, Li JQ. Effect of albumin infusion on preventing the deterioration of renal function in patients with spontaneous bacterial peritonitis. Chin $J$ Digest Dis. 2002;6:100-101.

70. Best LM, Freeman SC, Sutton AJ, et al. Treatment for hepatorenal syndrome in people with decompensated liver cirrhosis: a network meta-analysis. Cochrane Database Syst Rev. 2019;9: CD013103.

71. Bernardi M, Caraceni P, Navickis RJ, Wilkes MM. Albumin infusion in patients undergoing large-volume paracentesis: a meta-analysis of randomized trials. Hepatology. 2012;55 (4):1172-1181. doi:10.1002/hep.24786

72. Salerno F, Navickis RJ, Wilkes MM. Albumin infusion improves outcomes of patients with spontaneous bacterial peritonitis: a meta-analysis of randomized trials. Clin Gastroenterol Hepatol. 2013;11(2):123-130. doi:10.1016/j.cgh.2012.11.007

73. Leao GS, John Neto G, Jotz RF, Mattos AA, Mattos AZ. Albumin for cirrhotic patients with extraperitoneal infections: a meta-analysis. J Gastroenterol Hepatol. 2019;34(12):2071-2076. doi:10.1111/ jgh.14791.

74. Guo TT, Yang Y, Song Y, Ren Y, Liu ZX, Cheng G. Effects of midodrine in patients with ascites due to cirrhosis: systematic review and meta-analysis. $J$ Dig Dis. 2016;17(1):11-19. doi:10.1111/1751-2980.12304

75. Kwok CS, Krupa L, Mahtani A, et al. Albumin reduces paracentesis-induced circulatory dysfunction and reduces death and renal impairment among patients with cirrhosis and infection: a systematic review and meta-analysis. Biomed Res Int. 2013;2013:295153. doi:10.1155/2013/295153

76. Salerno F, Navickis RJ, Wilkes MM. Albumin treatment regimen for type 1 hepatorenal syndrome: a dose-response meta-analysis. $B M C$ Gastroenterol. 2015;15:167. doi:10.1186/s12876-015-0389-9
77. Kutting F, Schubert J, Franklin J, et al. Insufficient evidence of benefit regarding mortality due to albumin substitution in HCC-free cirrhotic patients undergoing large volume paracentesis. J Gastroenterol Hepatol. 2017;32(2):327-338.

78. Simonetti RG, Perricone G, Nikolova D, Bjelakovic G, Gluud C. Plasma expanders for people with cirrhosis and large ascites treated with abdominal paracentesis. Cochrane Database Syst Rev. 2019;6: CD004039.

79. Tandon P, Garcia-Tsao G. Renal dysfunction is the most important independent predictor of mortality in cirrhotic patients with spontaneous bacterial peritonitis. Clin Gastroenterol Hepatol. 2011;9 (3):260-265. doi:10.1016/j.cgh.2010.11.038

80. Fernandez J, Claria J, Amoros A, et al. Effects of albumin treatment on systemic and portal hemodynamics and systemic inflammation in patients with decompensated cirrhosis. Gastroenterology. 2019;157(1):149-162. doi:10.1053/j.gastro.2019.03.021

81. Ruiz-del-Arbol L, Monescillo A, Jimenez W, Garcia-Plaza A, Arroyo V, Rodes J. Paracentesis-induced circulatory dysfunction: mechanism and effect on hepatic hemodynamics in cirrhosis. Gastroenterology. 1997;113(2):579-586. doi:10.1053/gast.1997. v113.pm9247479

82. Licata G, Tuttolomondo A, Licata A, et al. Clinical Trial: high-dose furosemide plus small-volume hypertonic saline solutions vs. repeated paracentesis as treatment of refractory ascites. Aliment Pharmacol Ther. 2009;30(3):227-235. doi:10.1111/j.13652036.2009.04040.x

83. Tuttolomondo A, Di Raimondo D, Bellia C, et al. Immuneinflammatory and metabolic effects of high dose furosemide plus Hypertonic Saline Solution (HSS) Treatment in cirrhotic subjects with refractory ascites. PLoS One. 2016;11(12):e0165443. doi:10.1371/journal.pone.0165443

84. Hartog CS, Natanson C, Sun J, Klein HG, Reinhart K. Concerns over use of hydroxyethyl starch solutions. BMJ. 2014;349:g5981. doi:10.1136/bmj.g5981

85. Bernardi M, Caraceni P, Navickis RJ. Does the evidence support a survival benefit of albumin infusion in patients with cirrhosis undergoing large-volume paracentesis? Expert Rev Gastroenterol Hepatol. 2017;11(3):191-192.

86. Angeli P, Gines P, Wong F, et al. Diagnosis and management of acute kidney injury in patients with cirrhosis: revised consensus recommendations of the International Club of Ascites. Gut. 2015;64(4):531-537. doi:10.1136/gutjnl-2014-308874

87. Gines P, Schrier RW. Renal failure in cirrhosis. $N$ Engl J Med. 2009;361(13):1279-1290. doi:10.1056/NEJMra0809139

88. Ortega R, Gines P, Uriz J, et al. Terlipressin therapy with and without albumin for patients with hepatorenal syndrome: results of a prospective, nonrandomized study. Hepatology. 2002;36(4 Pt 1):941-948. doi:10.1053/jhep.2002.35819

89. Chinese Society of Hepatology CMA, Xu X, Duan Z, et al. Chinese guidelines on the management of ascites and its related complications in cirrhosis. Hepatol Int. 2019;13(1):1-21. doi:10.1007/ s12072-018-09923-2.

90. Di Pascoli M, Fasolato S, Piano S, Bolognesi M, Angeli P. Longterm administration of human albumin improves survival in patients with cirrhosis and refractory ascites. Liver Int. 2019;39 (1):98-105. doi:10.1111/liv.13968.

91. Sola E, Sole C, Gines P. New strategies for the management of decompensated cirrhosis: long-term albumin administration for everyone? Hepatology. 2019;69(5):2289-2291. doi:10.1002/hep.30357

92. McCabe C, Claxton K, Culyer AJ. The NICE cost-effectiveness threshold: what it is and what that means. PharmacoEconomics. 2008;26(9):733-744. doi:10.2165/00019053-200826090-00004

93. Caraceni P, Tufoni M, Zaccherini G, et al. On-treatment serum albumin level can guide long-term treatment in patients with cirrhosis and uncomplicated ascites. J Hepatol. 2020. doi:10.1016/j. jhep. 2020.08 .021 
94. Caraceni P, Angeli P, Prati D, et al. AISF-SIMTI position paper: the appropriate use of albumin in patients with liver cirrhosis. Blood Transfusion. 2016;14(1):8-22.

95. Brunkhorst FM, Engel C, Bloos F, et al. Intensive insulin therapy and pentastarch resuscitation in severe sepsis. $N$ Engl $\mathrm{J}$ Med. 2008;358(2):125-139. doi:10.1056/NEJMoa070716

96. Perner A, Haase N, Guttormsen AB, et al. Hydroxyethyl starch 130/0.42 versus Ringer's acetate in severe sepsis. $N$ Engl J Med. 2012;367(2):124-134. doi:10.1056/NEJMoa1204242

97. Myburgh JA, Finfer S, Bellomo R, et al. Hydroxyethyl starch or saline for fluid resuscitation in intensive care. $N \mathrm{Engl} \mathrm{J} \mathrm{Med.}$ 2012;367(20):1901-1911. doi:10.1056/NEJMoa1209759

98. European Medicines Agency (EMA). PRAC confirms that hydroxyethyl-starch solutions (HES) should no longer be used in patients with sepsis or burn injuries or in critically ill patients; 2013. Available from: https:/www.ema.europa.eu/en/news/pracconfirms-hydroxyethyl-starch-solutions-hes-should-no-longer-beused-patients-sepsis-burn. Accessed May 2020.

99. Cohen D. EMA calls for hydroxyethyl starch solutions to be taken off market. BMJ. 2018;360:k225. doi:10.1136/bmj.k225

100. European Medicines Agency (EMA). Assessment report for solutions for infusion containing hydroxyethyl starch. Available from: https://www.ema.europa.eu/en/documents/referral/hydroxyethylstarch-article-107i-procedure-prac-assessment-report_en.pdf. Accessed May 2020.
101. US Food and Drug Adminstration. Highlights of Prescribing Information: voluven (HES). 2014. Available from: https://www. fda.gov/media/72764/download. Accessed May 2020

102. Vincent JL, Russell JA, Jacob M, et al. Albumin administration in the acutely ill: what is new and where next? Critical Care. 2014;18 (4):231.

103. Gluud LL, Christensen K, Christensen E, Krag A. Systematic review of randomized trials on vasoconstrictor drugs for hepatorenal syndrome. Hepatology. 2010;51(2):576-584. doi:10.1002/ hep. 23286

104. Banares R, Bernardi M. Long-term albumin administration in patients with decompensated cirrhosis. It is time for a reappraisal. Liver Int. 2019;39(1):45-48. doi:10.1111/liv.13996

105. Kunkel HG, Labby DH, Ahrens EH, Shank RE, Hoagland CL. The use of concentrated human serum albumin in the treatment of cirrhosis of the liver. J Clin Invest. 1948;27(3 Pt 1):305-319. doi:10.1172/JCI101959

106. Wilkinson P, Sherlock S. The effect of repeated albumin infusions in patients with cirrhosis. Lancet. 1962;2(7266):1125-1129. doi:10.1016/S0140-6736(62)90895-4

\section{Publish your work in this journal}

Hepatic Medicine: Evidence and Research is an international, peerreviewed, open access journal covering all aspects of adult and pediatric hepatology in the clinic and laboratory including the following topics: Pathology, pathophysiology of hepatic disease; Investigation and treatment of hepatic disease; Pharmacology of drugs used for the treatment of hepatic disease. Issues of patient safety and quality of care will also be considered. The manuscript management system is completely online and includes a very quick and fair peer-review system, which is all easy to use. Visit http://www.dovepress.com/ testimonials.php to read real quotes from published authors 